\title{
Watershed prioritization for soil and water conservation aspect using GIS and remote sensing: PCA-based approach at northern elevated tract Bangladesh
}

\author{
Riad Arefin ${ }^{1} \cdot$ Md. Mohirul Islam Mohir ${ }^{2} \cdot$ Jahangir Alam $^{3}$
}

Received: 1 May 2019 / Accepted: 3 March 2020 / Published online: 14 March 2020

(c) The Author(s) 2020

\begin{abstract}
The current study has been derived to understand morphometric parameters to pledge the reduction in the proclaimed drought influence for climate change. Watershed prioritization has been studied using the geographical information system and remote sensing techniques for soil erosion and water preservation measure at Plio-Pleistocene elevated tract in Bangladesh. Secondary data, i.e., SRTM DEM and the topographical sheets, have been used for the drainage network identification. Seventeen watersheds of fifth order and three watersheds of sixth order are selected for the whole study. Sixteen basic morphometric parameters that are categorized as areal, linear and relief aspects have been used for the study area. The study area comprises sixth stream order that has been obtained using a stream threshold value of $100-\mathrm{m}$ length. Morphometric analysis is suitable for water and soil conservation practice where groundwater and relevant data sets are not available. For the categorization and correlation of the morphometric parameters, principal component analysis (PCA) has been used in the present study. PCA analysis is more suitable, well-known and widely used method for its simplicity to choose more influencing parameters (correlated parameters) that are responsible for watershed prioritization. Strongly correlated components $\left(D_{\mathrm{d}}, R_{\mathrm{c}}, R_{\mathrm{e}}\right.$ and $\left.R_{\mathrm{b}}\right)$ are used for the compound parameter $\left(C_{\mathrm{p}}\right)$ and final priority $\left(R_{\mathrm{p}}\right)$ calculation. Low $C_{\mathrm{p}}$ value is suitable for water and soil conservation measure. Therefore, the corresponding low $C_{\mathrm{p}}$ has been taken as one for final priority ranking $\left(R_{\mathrm{p}}\right)$ purpose, then second lowest value as two, and so on.
\end{abstract}

Keywords GIS · RS · Watershed $\cdot$ Morphometric analysis $\cdot$ Prioritization $\cdot$ PCA $\cdot$ Plio-Pleistocene $\cdot$ Bangladesh

\section{Introduction}

High inhabitant's dilation, mercurial urbanization, climate change along with the jerky frequency, less vigor of rainfall make water management and storage plans difficult, but there is a compelling need for the appraisal of water resources for livelihood and economics all over the world (Singh et al. 2014). Water is the primary safeguard against drought and plays remarking aid in food storage for an

Riad Arefin

riad.gmru@gmail.com

1 Department of Geology and Mining, University of Rajshahi, P.O. Box 6205, Rajshahi, Bangladesh

2 Department of Earth Science, Shimane University, P.O. Box 690-0823, Matsue, Japan

3 Department of Statistics, University of Rajshahi, P.O. Box 6205, Rajshahi, Bangladesh ever-growing population and urbanization at local, national and global levels that staying at the brink of collapse (Singh et al. 2013; Jha et al. 2007).

Morphometric analyses are mathematical measurement of the earth's surface, its shape and dimension of land form that provides knowledge about the hydrological nature of the surface rock (Agarwal 1998; Reddy et al. 2002). The morphometric study describes basin characters and gives the concept of geological and geomorphic history for the drainage area (Strahler 1964). Literature review shows that morphometric analyses involve evaluation of linear, aerial and relief parameters (Choudhari et al. 2018; Farhan et al. 2017; Rahaman et al. 2015; Singh et al. 2014; Meshram and Sharma 2015; Gajbhiye et al. 2014; Rai et al. 2014, 2017a, b, 2018, 2019; Magesh et al. 2012; Sharma et al. 2018).

Drainage network provides information about local elevation gradient, the difference in rock resistance against erosion, structural control, the geological and geomorphological activity of the watershed (Rai et al. 2014). In the absence 
of hydrological data, geomorphological parameters help for characterizing watershed in the context of geomorphological and climatic characteristics of a basin (Meshram and Sharma 2018).

According to Chopra et al. (2005), Gajbhiye et al. (2014), Rahaman et al. (2015), watershed is an ideal part for land and water resource management where rainwater (surface runoff), melting snow or ice move toward a particular location of lower elevation, called an outlet of the basin to join another water unit such as a river, lake, reservoir, estuary, wetland, sea or ocean. Soil erosion and water conservation measure for a large area is difficult. Therefore, large area is divided into sub-watershed using drainage network (Meshram and Sharma 2015).

Morphometric analyses are essential for detection of water recharge site, watershed delineation, modeling, groundwater prospect mapping, geotechnical investigation, flow intensity and runoff (Ozdemir and Bird 2009; Magesh et al. 2011; Thomas et al. 2012).

Different techniques are available for morphometric analysis, viz. Arc Hydro Tool, Ilwis, Basin 4, Arc GIS, HEC-GeoRAS, etc. These softwares are used nowadays for automatic watershed extraction from digital elevation model (DEM). Markose et al. (2014) use 'bearing, azimuth and drainage (bAd) calculator' which is a modern and easy technique for the extraction of watershed morphometric parameters. Akram et al. (2012) briefly described the watershed delineation from DEM using Arc GIS.

For the detection of the prioritized watershed, other methods are quantitative analysis, statistic methods, fuzzy logic, analytical hierarchical process (AHP) (Rahaman et al. 2015). Scientists, viz. Gurmessa and Bárdossy (2009), Brown (1992), Pandžić and Trninić (1992), Bouvier et al. (2003), Samani et al. (2007), Al-Alawi et al. (2008), have used PCA analysis for their works in different fields of scientific research. Mishra and Satyanarayana (1988) applied principal component analysis with varimax rotation on ten geomorphic parameters that are classified into drainage, slope and shape components at Damodar Valley watershed. Jaiswal et al. (2014), Rahaman et al. (2015) used morphometric indices and the fuzzy analytical hierarchy, including the Saaty analytical hierarchy process (AHP) to prioritize watersheds for determination of the controlling factor. Javed et al. (2011)and Puno and Puno (2019) have carried out watershed prioritization using morphometric analysis and land use/land cover (LULC) parameters. Javed et al. (2011) showed that the result of prioritization on the basis of morphometric analysis revealed that SW 7 and SW 10 have fall under very high priority, whereas SW 6, SW 11 and SW 13 also fall under very high priority on the basis of land use/land cover (LULC) analysis. However, on the superimposition of the thematic layers of morphometric and land use/land cover in GIS environment, only SW 14 has indicated a common priority, whereas the rest of sub-watersheds show little or no correlation. The sub-watersheds which are falling under very high priority may be taken up for implementation of soil and water conservation measures. Puno and Puno (2019) showed that from 14 sub-watersheds, SW 13, SW 14 and SW 4 were observed as the most susceptible to land degradation and soil erosion; therefore, immediate attention for soil and water conservation is important for these watersheds.

Previously, drainage network and watersheds were determined using topographical sheet and field survey data. But now the digital elevation model (DEM) with the combination of topographical sheet and field survey data is used in rapid, more precise, updated and cost-effective manner for the watershed analysis (Maathuis and Wang 2006; Moore et al. 1991). According to Choudhari et al. (2018) and Sreedevi et al. (2013), morphometric parameters were derived from Shuttle Radar Topographic Mission (SRTM) DEM and works on C-band interferometry radar setup. Yadav et al. (2014) used CARTOSAT DEM for the morphometric analysis purpose. The study has been carried out aiming to implication:

- Watershed prioritization for soil erosion and water preservation purpose using the morphometric study.

- Application of principal component analysis (PCA) for watershed prioritization.

- Completing spatial maps that describe the final priority for the 20 sub-watersheds.

- Propose suitable soil erosion and water preservation measures for the watershed.

GIS and remote sensing techniques are helpful for rapid and precise analysis on a large scale with the lower cost.

\section{Study area}

The study area is located at northern part of Bangladesh and comprises terrace like geomorphic features that was formed due to the sea level rise and fall. Oldest alluvium of Plio-Pleistocene age has exposed at the surface and comprises $1931 \mathrm{~km}^{2}$ area. Tectonically, the proposed area occupies the regional plate (Precambrian Indian Platform) that covers the saddle and the shelf area at the northwestern part of Bangladesh. The proposed area is relatively higher than the adjoining floodplain. The contour line map suggests that two terrace levels exist in this area; one remains between 19.8 and $22.9 \mathrm{~m}$ elevation, and the other is $40 \mathrm{~m}$ elevation from average mean sea level (AMSL). Therefore, during the rainy season, the area remains free from flooded water and rain water drained through narrow intermittent streams. About $47 \%$ area of the region is classified as highland, $41 \%$ 
as medium highland, and the rest are lowlands. Figure 1 shows the study area map.

\section{Slope}

According to the Magesh et al. (2011) and Gayen et al. (2013), slope is followed by the climato-morphogenic influence where rocks of varying resistance are existing. Slope map was generated from SRTM DEM. Figure 2 shows the slope map of the study area. Berhanu et al. (2013) classified slope as flat, gentle, moderate, and steep. Slope ranges from 0 to 29 degree for the proposed area. Analysis shows that $82 \%$ area comprises $0^{\circ}-3^{\circ}, 16 \%$ area comprises $>3^{\circ}-8^{\circ}$,
$1.5 \%$ areas comprises $>8^{\circ}-15^{\circ}$, and $0.5 \%$ area comprises $15^{\circ}-29^{\circ}$

\section{Land use/land cover (LULC)}

Four land use-type classes were detected for the proposed area, viz. cultivated land, water body, sand bar and settlement (Fig. 3), where cultivated land comprises $91 \%$ area, water body comprises $1 \%$ area, sand bar comprises $0.5 \%$ area, and settlement comprises $8 \%$ area. Land use type describes the knowledge on infiltration, soil moisture, groundwater, surface water, etc. (Ibrahim-Bathis and Ahmed 2016).

Fig. 1 Map of study area
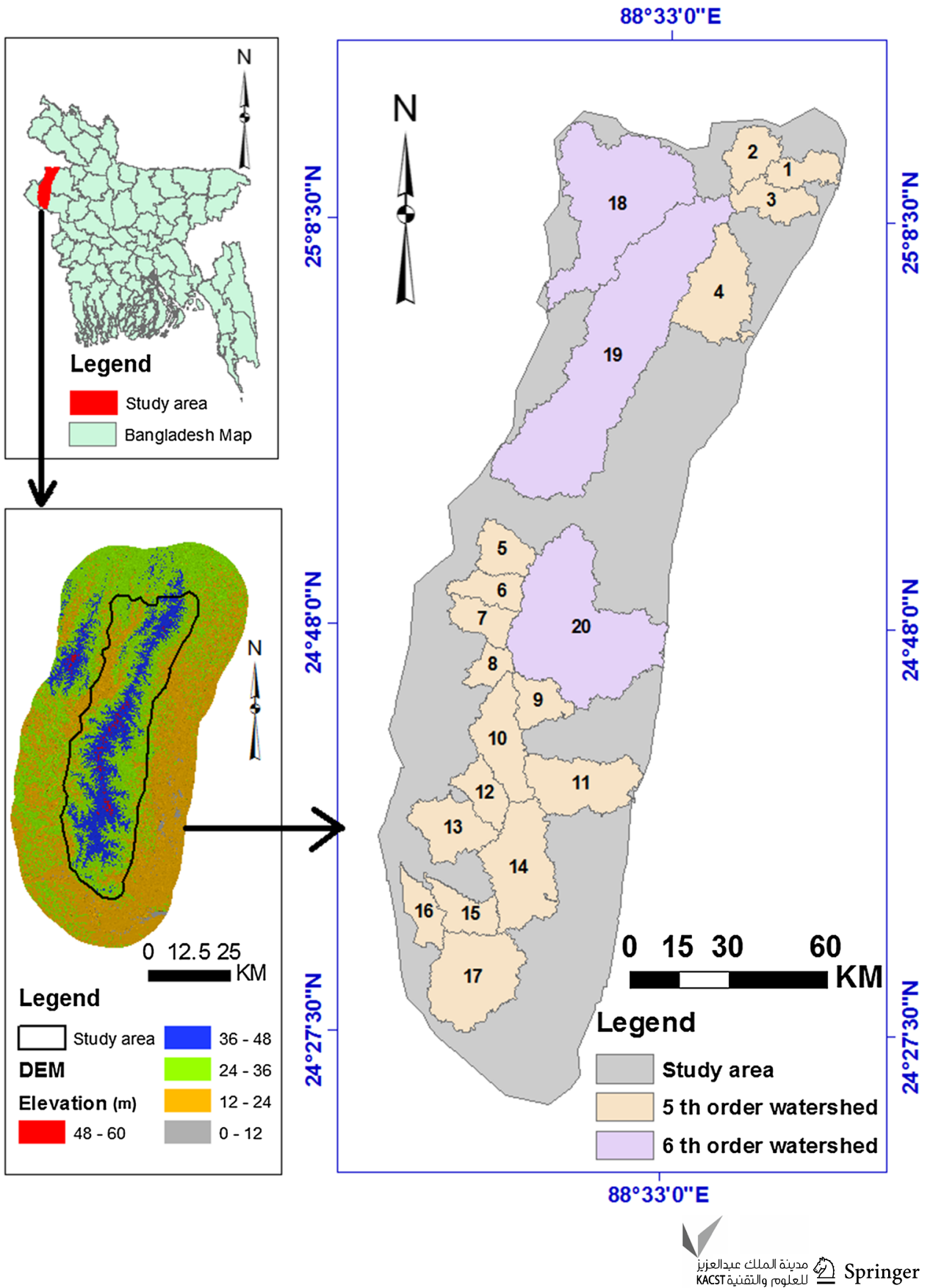


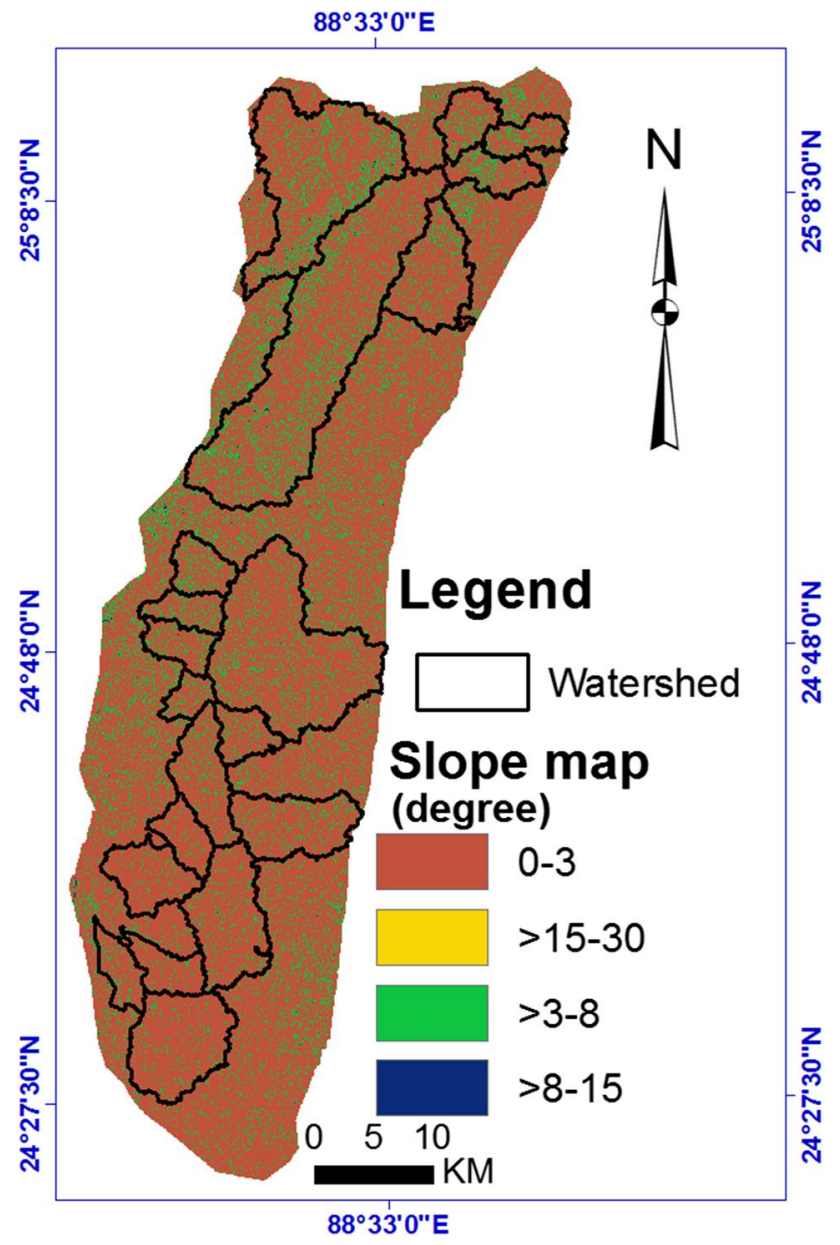

Fig. 2 Slope map of the proposed area

\section{Aspect map}

Aspect map produces from SRTM DEM that is shown in Fig. 4. Aspect value represents the compass direction of the slope (Magesh et al. 2011). Aspect controls the influence of climate because the sun shines incident on the soil to west during the warmer time in the afternoon, so slope will become hotter than east-facing slope, and eastern-facing slopes have a high moisture content and low evaporation rate. Aspect also controls the distribution of vegetation.

\section{Surface lithology}

According to Akinlalu et al. (2017), lithology controls groundwater recharge because fine grain size materials decrease permeability. McGarry (2006) describes the role of lithology as an important factor for the physical conditions of soil like structure, porosity, adhesion and consistency. Lithological information was obtained from the Geological Survey of Bangladesh (GSB 2001). Three types of soil layer, namely clay (covering $93 \%$ area), marsh clay and peat (3\%

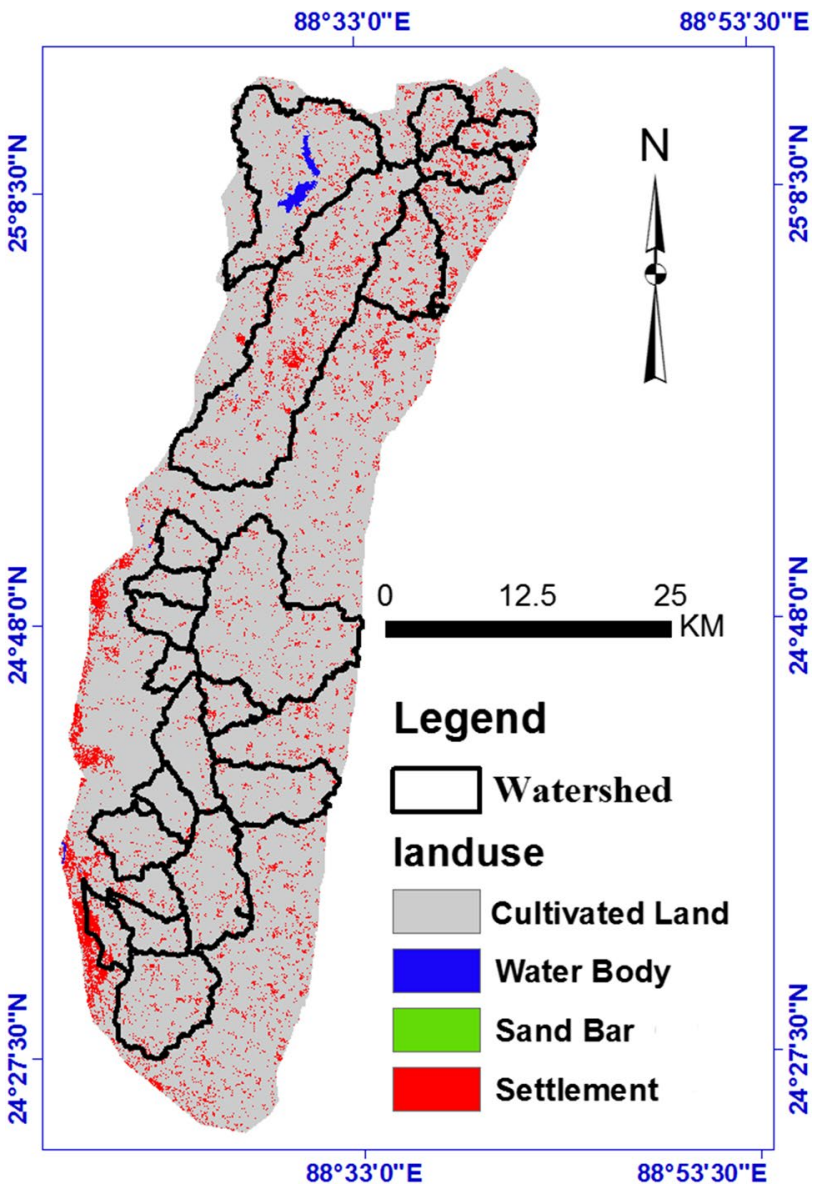

Fig. 3 Land use map of the proposed area

area) and alluvial silt (4\% area), were found for the proposed area. Alluvial silt has a relatively high porosity. Figure 5 shows the exposed soil map of the target area.

\section{Materials and methodology}

Watershed character and their management require knowledge of topography, drainage network, water divide, channel length, geomorphological and geological setup of an area (Sreedevi et al. 2013). Quantitative analyses of the morphometric parameters provide detailed information on hydrological condition and rock formation stability, their permeability, storage capacity that shows the yield of the basin. In the research paper, integrated secondary data sets have been used that were obtained from different sectors, as provided in Table 1. Topographical sheets were geometrically rectified and geo-referenced by taking ground control points (GCPs) using UTM projection and WGS 1984 datum. Drainage network and all parameters were calculated using SRTM DEM using ARC GIS. The workflow adopted for the computation of morphometric parameters is shown in Fig. 6. 


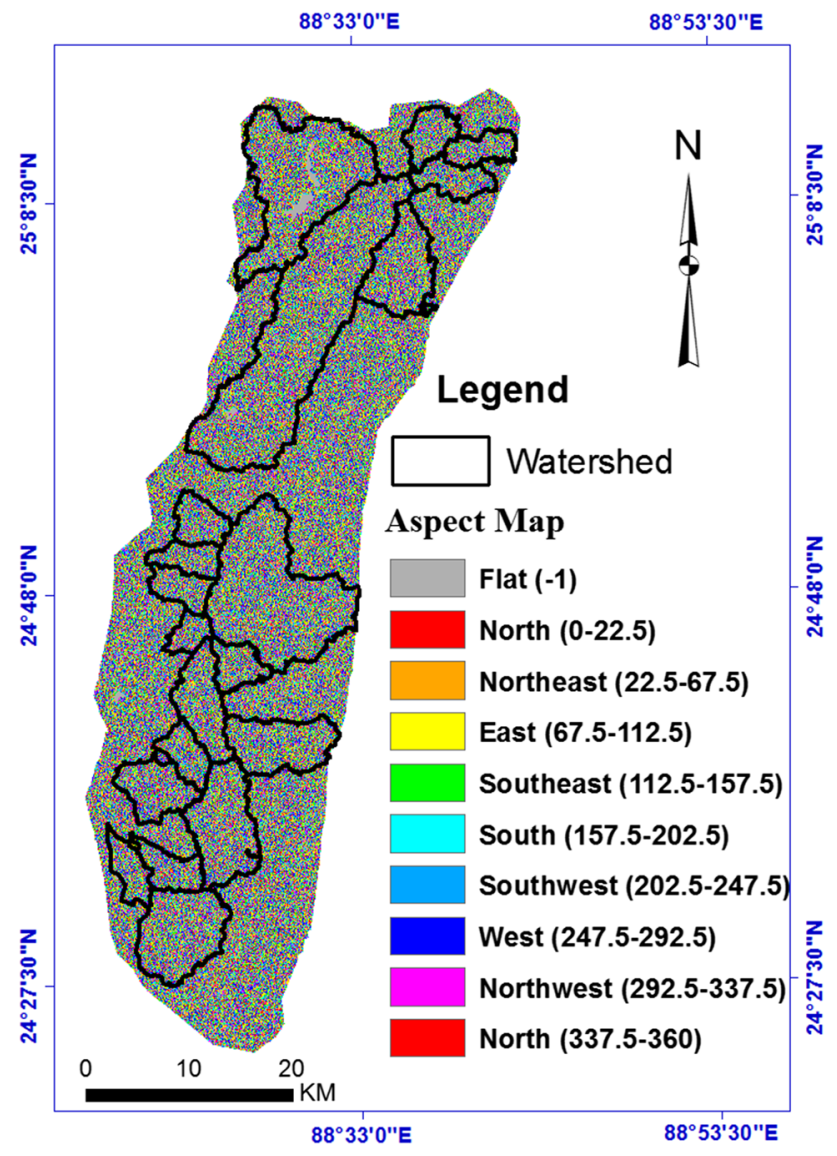

Fig. 4 Aspect map of the proposed area

The methodology includes drainage network identification and watershed extraction using DEM in combination of Arc GIS and Arc Hydro tool used for this study. Fifteen parameters are calculated for morphometric analysis. PCA analysis is used for reduction in the parameters and determines the more sensitive parameter for watershed prioritization. Morphometric study will help for water resource management for this region.

\section{Results and discussion}

\section{Stream network determination}

Fill DEM The original DEM contains some depressions that create termination for the continuity of the stream length. To get proper drainage map, the DEM must be filled. The task has been completed using fill of hydrology tool of Arc GIS tool.

Flow direction The filled DEM was used to generate the flow direction for each cell. Values range from 1 to

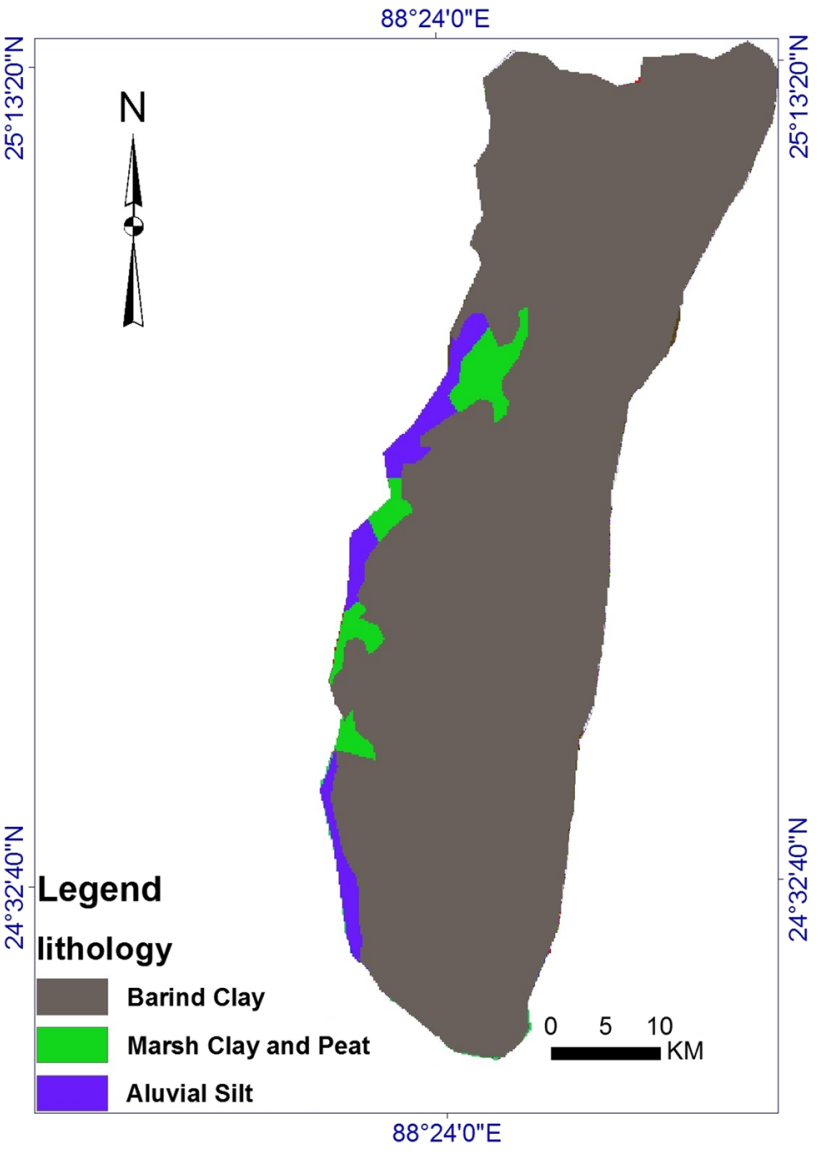

Fig. 5 Lithology map of the proposed area

255. The eight-direction D8 method was introduced by O'Callaghan and Mark (1984) and widely used in recent time for flow direction detection (Band 1986; Marks et al. 1984; Mark 1984).

Flow accumulation Using the flow accumulation tool of Arc GIS, a flow accumulation raster has been created. The flow direction raster has been used to prepare the flow accumulation raster.

Stream threshold Drainage network generation is critical to extract from DEM (Bertolo 2000). For the proposed area, stream threshold value was taken $100 \mathrm{~m}$. A reference stream has been used for stream network. The whole step was executed using con tool of Arc GIS. Con tool is existing in the arc toolbox $>$ spatial analyst tools $>$ conditional $>$ con of ARC GIS.

Stream order Stream order was generated from the stream network raster and flow direction raster. Sixth-order stream of 3 nos. and fifth-order stream of 17 nos. stream networks were generated for the proposed location.

Stream link From stream order raster attribute table, fifth- and sixth-order stream selected individually and 
Table 1 Data sources and characteristics

\begin{tabular}{ll}
\hline Data & Sources \\
\hline Slope map & DEM (USGS 1 arc second), UTM-45, WGS 1984 \\
Aspect map & DEM (USGS 1 arc second), UTM-45, WGS 1984 \\
Topographical sheet & Topographical sheet in 1955 and 1:250,000 scales \\
& (https://legacy.lib.utexas.edu/maps/ams/india/) \\
Soil map & GSB (Geological Survey of Bangladesh) \\
Land use map & Landsat image OLI-2016, row/path-43/138 \\
Drainage network & DEM (USGS 1 arc second), UTM-45, WGS 1984 \\
Reference stream & Barind Multipurpose Development Authority (BMDA). \\
\hline
\end{tabular}

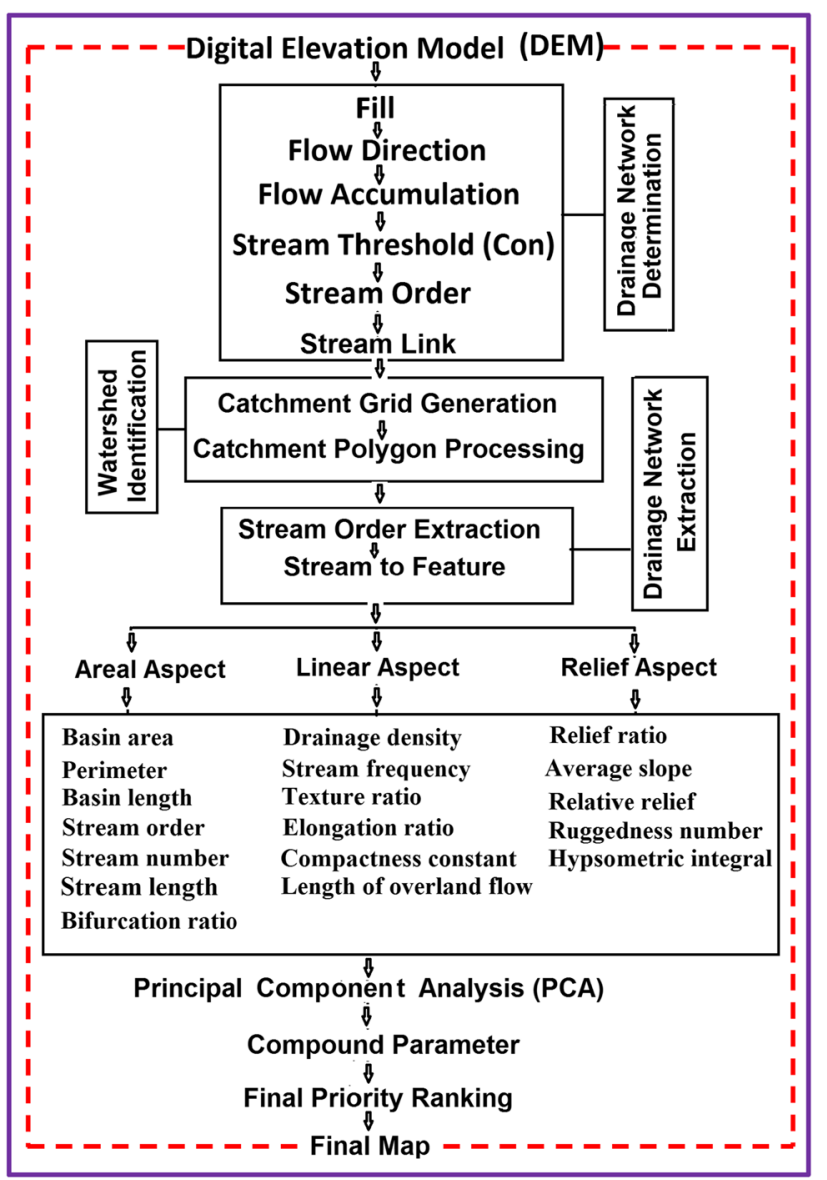

Fig. 6 Workflow for the whole study

stream link are also created individually. The step is performed using the stream link tool of Arc GIS.

\section{Watershed determination}

Catchment grid generation: This step is conducted using Arc Hydro tool. It is an extension of Arc GIS. Flow direction raster and stream link raster are used for catchment grid generation. For fifth- and sixth-order streams, catchment grid delineation is conducted separately (two times for fifth- and 6th-order stream links). The output catchment grid is a raster.

Catchment polygon processing: From catchment raster file, the fifth- and sixth-order catchment shape files are generated. This step is also conducted using the Arc Hydro tool. Fifth-order watersheds of 17 nos. and sixth-order watersheds of 3 nos. are identified.

\section{Drainage network extraction}

Stream order extraction For extraction of drainage network, fifth-order watersheds of 17 nos. and sixth-order watersheds of 3 nos. are used individually for extraction of the stream order raster. The steps are applied using the extraction tool of Arc GIS.

Stream to feature For morphometric calculation, stream feature shape file is generated from the extracted stream order raster using stream to raster tool of Arc GIS.

\section{Basic parameter}

The basin area $(A)$, perimeter $(P)$ and basin length $(L)$ of the individual watershed were determined using Arc GIS. Table 2 describes the procedure, and Table 3 describes the value of basin area, perimeters and length. Maximum $215 \mathrm{~km}^{2}$ basin area, $108 \mathrm{~km}$ perimeter and $27.74 \mathrm{~km}$ basin length were detected (watershed 19), and minimum $19 \mathrm{~km}^{2}$ basin area, $12 \mathrm{~km}$ perimeter and $6.99 \mathrm{~km}$ basin length were detected (watershed 8).

\section{Stream order (U)}

Gravelius (1914), Horton (1945) and Strahler (1957, 1964) describe stream order in different ways. Strahler (1964) method was used to determine stream order for its simplicity. Calculation is given in Table 2. Fifth-order stream of seventeen watersheds and sixth-order stream of three watersheds were found using stream threshold value $100 \mathrm{~m}$ (length). Dendrite to the sub-dendrite stream has been obtained for the proposed site. According to Choudhari et al. (2018), dendritic drainage pattern shows homogeneous and uniform 
Table 2 Calculation of morphometric parameter for all watersheds

\begin{tabular}{|c|c|c|c|}
\hline Parameters & Equation & Eq. no. & References \\
\hline Watershed area $A\left(\mathrm{~km}^{2}\right)$ & Arc GIS & & Nooka et al. (2005) \\
\hline Perimeter $(P)(\mathrm{km})$ & Arc GIS & & Nooka et al. (2005) \\
\hline Stream order $(U)$ & Hierarchical rank & & Strahler (1964) \\
\hline Number of stream $\left(N_{\mathrm{u}}\right)$ & Individual order stream number & & Horton (1945) \\
\hline Stream length $(L)(\mathrm{km})$ & Individual order length & & Horton (1945) \\
\hline Bifurcation ration $\left(R_{\mathrm{b}}\right)$ & $\begin{array}{c}R_{\mathrm{b}}=N_{\mathrm{u}} / N_{\mathrm{u}+1} \ldots \ldots \ldots \ldots \ldots \ldots \ldots \ldots \ldots \ldots \ldots \ldots \ldots \\
\text { where } N_{\mathrm{u}}=\text { total number of stream segments of order } \mathrm{u} \text { and } \\
N_{\mathrm{u}+1}=\text { number of stream segment of next higher order }\end{array}$ & 1 & Schumm (1956) \\
\hline Mean bifurcation ration $\left(R_{\mathrm{bm}}\right)$ & $R_{\mathrm{bm}}=$ Avg. $R_{\mathrm{b}}$ of all orders $\ldots \ldots \ldots \ldots \ldots \ldots$ & 2 & Strahler (1957) \\
\hline Drainage density $\left(D_{\mathrm{d}}\right)$ & $\begin{array}{l}D_{\mathrm{d}}=L_{\mathrm{u}} / A \ldots \ldots \ldots \ldots \ldots \ldots \ldots \ldots \ldots \ldots \ldots \ldots \ldots \ldots \ldots \ldots \\
\text { where } L_{\mathrm{u}}=\text { total stream length of all orders and } A=\text { area of the } \\
\text { basin }\end{array}$ & 3 & Horton (1945) \\
\hline Stream frequency $\left(F_{\mathrm{s}}\right)$ & $\begin{array}{l}F_{\mathrm{s}}=N_{\mathrm{u}} / A \ldots \ldots \ldots \ldots \ldots \ldots \ldots \ldots \ldots \ldots \ldots \ldots \ldots \ldots \ldots \\
\text { where } N_{\mathrm{u}}=\text { total number of streams of all orders and } A=\text { area of the } \\
\text { basin }\left(\mathrm{km}^{2}\right)\end{array}$ & 4 & Horton (1945) \\
\hline Texture ratio $(T)$ & $\begin{array}{l}T=N_{\mathrm{u}} / P \ldots \ldots \ldots \ldots \ldots \ldots \ldots \ldots \ldots \ldots \ldots \ldots \ldots \ldots \ldots \ldots \ldots \ldots \\
\text { where } N_{\mathrm{u}}=\text { total number of streams of all orders and } P=\text { perimeter } \\
\quad(\mathrm{km})\end{array}$ & 5 & Horton (1945) \\
\hline Elongation ratio $\left(R_{\mathrm{e}}\right)$ & $\begin{array}{l}R_{\mathrm{e}}=\left(2 / L_{\mathrm{b}}\right) \times(A / P) 0.5 \ldots \ldots \ldots \ldots \ldots \ldots \\
\text { where } L_{\mathrm{b}}=\text { length of basin }(\mathrm{km}) \text { and } A=\text { area of the basin }\left(\mathrm{km}^{2}\right)\end{array}$ & 6 & Schumm (1956) \\
\hline Circularity ratio $\left(R_{\mathrm{c}}\right)$ & $\begin{array}{l}R_{\mathrm{c}}=4 \pi A / P^{2} \ldots \ldots \ldots \ldots \ldots \ldots \ldots \ldots \ldots \ldots \ldots \ldots \ldots \ldots \\
\text { where } R_{\mathrm{c}}=\text { circulatory ratio, } A=\text { area of the basin }\left(\mathrm{km}^{2}\right), \text { and } \\
\quad P=\text { perimeter }(\mathrm{km})\end{array}$ & 7 & Miller (1953) Strahler (1964) \\
\hline Form factor $\left(R_{\mathrm{f}}\right)$ & $\begin{array}{l}\mathrm{Ff}=A / L^{2} \ldots \ldots \ldots \ldots \ldots \ldots \ldots \\
\text { where } A=\text { area of the basin }\left(\mathrm{km}^{2}\right) \text { and } L=\text { basin length }(\mathrm{km})\end{array}$ & 8 & Horton $(1932 ; 1945)$ \\
\hline Shape factor $\left(B_{\mathrm{s}}\right)$ & $\begin{array}{l}B_{\mathrm{S}}=L_{\mathrm{b}}^{2} / A \ldots \ldots \ldots \ldots \ldots \ldots \ldots \ldots \ldots \ldots \ldots \ldots \\
\text { where } A=\text { area of the basin }\left(\mathrm{km}^{2}\right) \text { and } L_{\mathrm{b}} \text { (basin } \\
\text { length) }=1.312 \times A^{0.568}\end{array}$ & 9 & Nooka et al. (2005), Horton (1932) \\
\hline Compactness factor $\left(C_{\mathrm{c}}\right)$ & $\begin{array}{l}C_{\mathrm{c}}=0.2821 P / A 0.5 \ldots \ldots \ldots \ldots \ldots \\
\text { where } A=\text { area of the basin }\left(\mathrm{km}^{2}\right) \text { and } P=\text { perimeter of the basin } \\
\quad(\mathrm{km})\end{array}$ & 10 & Horton (1945) \\
\hline Length of over land flow $\left(L_{\mathrm{o}}\right)$ & $\begin{array}{l}L_{\mathrm{o}}=1 /(2 \mathrm{D}) \ldots \ldots \ldots \ldots \ldots \ldots \ldots \ldots \ldots \ldots \ldots \ldots \ldots \ldots \ldots \\
\text { where } D=\text { drainage density of the basin }\end{array}$ & 11 & Horton (1945) \\
\hline Relief ratio $\left(R_{\mathrm{h}}\right)$ & $\begin{array}{l}R_{\mathrm{h}}=R / L \ldots \ldots \ldots \ldots \ldots \ldots \ldots \ldots \ldots \ldots \ldots \ldots \ldots \ldots \ldots \ldots \\
\text { where } R=\text { basin relief and } L=\text { longest axis of major river (basin } \\
\text { length) in } \mathrm{km}\end{array}$ & 12 & Schumm (1956) \\
\hline Ruggedness number $\left(R_{\mathrm{N}}\right)$ & $\begin{array}{l}R_{\mathrm{N}}=R \times D_{\mathrm{d}} \ldots \ldots \ldots \ldots \ldots \ldots \ldots \ldots \ldots \ldots \ldots \ldots \ldots \ldots \ldots \ldots \ldots \ldots \\
\text { where } R=\text { basin relief and } D_{\mathrm{d}}=\text { drainage density }\end{array}$ & 13 & Schumm (1956) \\
\hline Hypsometric integral (HI) & $\begin{array}{l}f(x)=a_{\mathrm{o}}+a_{1} x+a_{2} x^{2}+a_{3} x^{3}+\cdots+a_{n} x^{n} \ldots \ldots \ldots \ldots \\
\text { where } f(x)=\text { relative-altitudes }(h / H) \text { and } x=\text { relative-areas }(a / A)\end{array}$ & 14 & Harlin (1978) \\
\hline
\end{tabular}

lithological resistance and tectonically stable area. The change in stream order suggests that streams flow from high altitude with less lithological variations. Rai et al. (2014) and Choudhari et al. (2018) notice that maximum stream order is found in first-order streams. Stream order is shown in Fig. 7, and values are given in Table 4.

\section{Stream number $\left(\boldsymbol{N}_{\mathrm{u}}\right)$}

$N_{\mathrm{u}}$ is reciprocal to the stream order. Stream number identification process is illustrated in Table 2. During stream number identification, it was obtained that the number of stream decreases as the stream order increases. Stream order and its size largely depend on the physiographical, geomorphological and geological conditions of the interested region (Rai et al. 2014). Different stream order and the total stream number of a particular order have been quantified using Arc GIS. $N_{\mathrm{u}}$ for individual watershed is described in Table 4.

\section{Stream length $\left(L_{u}\right)$}

Table 2 provides the calculation procedure of the stream length for a particular order of a watershed. Stream length was determined according to Horton (1945) law. Horton's 
Table 3 Basin parameters of the proposed watershed

\begin{tabular}{lllll}
\hline WS no. & WS name & $\begin{array}{l}\text { Basin area } \\
\left(\mathrm{km}^{2}\right)\end{array}$ & Perimeter $(\mathrm{km})$ & $\begin{array}{l}\text { Basin } \\
\text { length } \\
(\mathrm{km})\end{array}$ \\
\hline 1 & S1 & 27 & 18 & 8.54 \\
2 & S2 & 26 & 21 & 8.35 \\
3 & S3 & 30 & 21 & 9 \\
4 & S4 & 51 & 47 & 12.25 \\
5 & S5 & 22 & 20 & 7.6 \\
6 & S6 & 24 & 18 & 7.98 \\
7 & S7 & 25 & 18 & 8.17 \\
8 & S8 & 19 & 12 & 6.99 \\
9 & S9 & 26 & 19 & 8.35 \\
10 & S10 & 38 & 39 & 10.36 \\
11 & S11 & 39 & 47 & 10.52 \\
12 & S12 & 25 & 19 & 8.17 \\
13 & S13 & 34 & 32 & 9.73 \\
14 & S14 & 49 & 59 & 11.97 \\
15 & S15 & 30 & 20 & 9.06 \\
16 & S16 & 25 & 18 & 8.17 \\
17 & S17 & 40 & 61 & 10.67 \\
18 & S18 & 124 & 77 & 20.29 \\
19 & S19 & 215 & 108 & 27.74 \\
20 & S20 & 141 & 72 & 21.83 \\
\hline & & & &
\end{tabular}

second law suggested that as stream order increases, stream length decreases. It means the first-order stream has the maximum length. The stream length expresses the hydrological characteristics of the bedrock and the drainage extent of a basin. It explains the rock formation permeability. A small number but longer streams are formed in the well-drained watershed, where the soil layer is permeable (Sethupathi et al. 2011). The stream length is given in Table 4.

\section{Bifurcation ratio $\left(R_{b}\right)$}

According to Schumm (1956), $R_{\mathrm{b}}$ is the ratio of stream number of a particular order to the stream number of the next higher order (Eqs. 1 and 2 in Table 2). It is a dimensionless property and detects integration between streams of various orders. According to Horton (1945), $R_{\mathrm{b}}$ is an indicator of relief and erosion, while Strahler (1957) stated that $R_{\mathrm{b}}$ shows a small change with different environments, but the value is higher where strong geological control dominates. Lower $\mathrm{R}_{\mathrm{b}}$ values express structurally low disturbance in the watershed (Nag 1998; Strahler 1964; Vittala et al. 2004; Chopra et al. 2005). According to Strahler (1964), $R_{\mathrm{b}}$ value ranging from 3.0 to 5.0 indicates the area geologically stable or

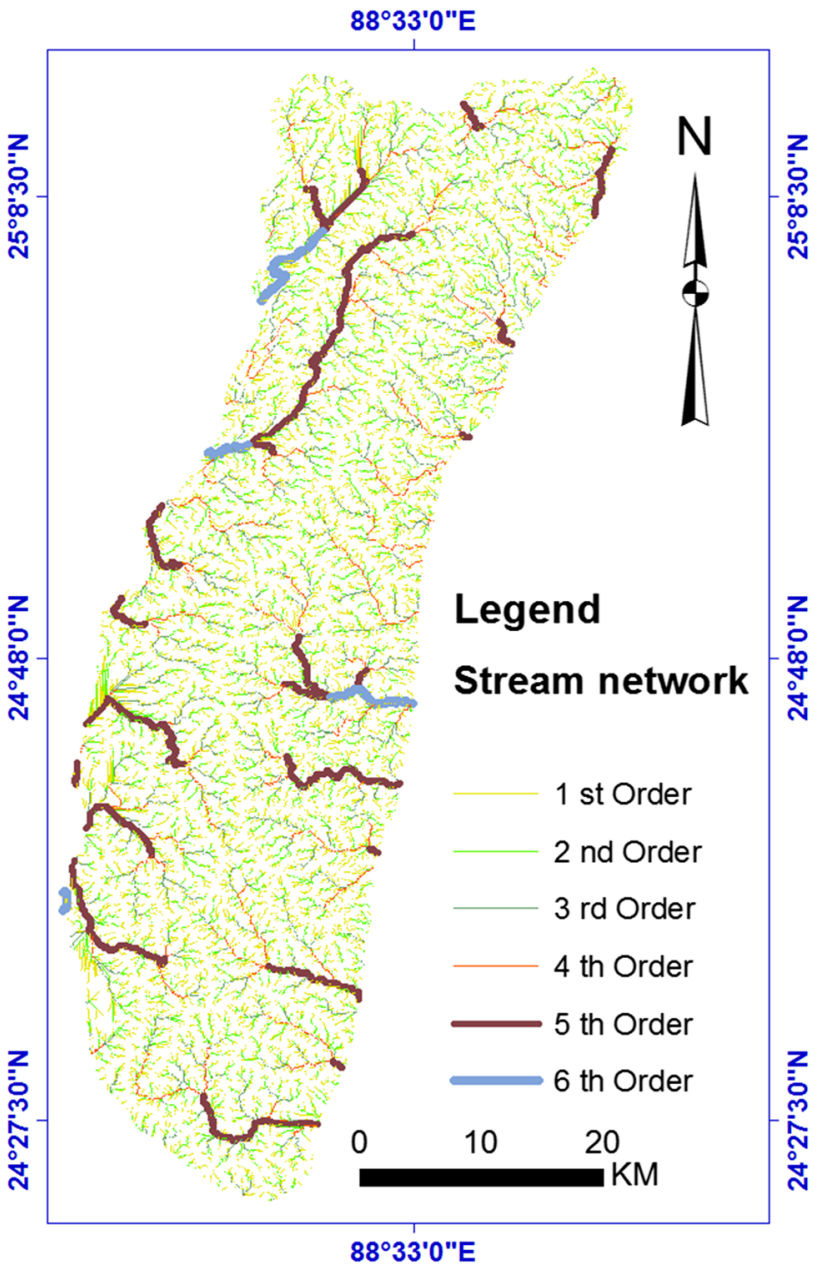

Fig. 7 Stream network of the proposed area

drainage pattern is negligible. $R_{\mathrm{b}}$ values for all watersheds are described in Table 4.

\section{Drainage density $\left(D_{d}\right)$}

According to Strahler (1964), $D_{\mathrm{d}}$ is the ratio of stream length to the area of the basin (Eq. 3). $D_{\mathrm{d}}$ depends on valley density, channel origin, relief, slope, climate and vegetation, soil and rock properties such as infiltration and soil resistance (Farhan et al. 2017) and landscape evolution processes. $D_{\mathrm{d}}$ for the proposed area is $1.36 \mathrm{~km} / \mathrm{km}^{2}$. High $D_{\mathrm{d}}$ indicates that basin soil is less resistive and high relief in association with weak and impermeable subsurface material, sparse vegetation, fine drainage texture, high runoff and erosion potential (Strahler 1964; Prasad et al. 2008). Maximum $D_{\mathrm{d}}$ was obtained as $3.71 \mathrm{~km} / \mathrm{km}^{2}$ (watershed 17) and minimum $1.22 \mathrm{~km} / \mathrm{km}^{2}$ (watershed 7) as shown in Table 5. Figure 8 shows the $D_{\mathrm{d}}$ map of the study area. 
Table 4 Linear aspects of watersheds

\begin{tabular}{|c|c|c|c|c|c|c|c|c|}
\hline \multirow[t]{2}{*}{ Sub-watershed } & \multirow[t]{2}{*}{ Parameters } & \multicolumn{6}{|c|}{ Stream order } & \multirow{2}{*}{$\begin{array}{l}\text { Mean bifurca- } \\
\text { tion ratio }\left(R_{\mathrm{b}}\right)\end{array}$} \\
\hline & & I & II & III & IV & $\mathrm{V}$ & VI & \\
\hline \multirow[t]{2}{*}{ Sub-watershed 1} & Stream no & 59 & 30 & 3 & 2 & 1 & - & \\
\hline & Stream length & 22 & 13 & 4 & 5 & 0.5 & - & 3.87 \\
\hline \multirow[t]{2}{*}{ Sub-watershed 2} & Stream no & 118 & 39 & 3 & 2 & 1 & - & \\
\hline & Stream length & 26 & 11 & 8 & 6 & 0.5 & - & 4.88 \\
\hline \multirow[t]{2}{*}{ Sub-watershed 3} & Stream no & 92 & 27 & 3 & 1 & 2 & - & \\
\hline & Stream length & 22 & 16 & 4 & 7 & 1 & - & 3.98 \\
\hline \multirow[t]{2}{*}{ Sub-watershed 4} & Stream no & 187 & 36 & 8 & 2 & 1 & - & \\
\hline & Stream length & 55 & 35 & 22 & 8 & 1 & - & 3.92 \\
\hline \multirow[t]{2}{*}{ Sub-watershed 5} & Stream no & 103 & 20 & 18 & 2 & 1 & - & \\
\hline & Stream length & 24 & 6 & 12 & 4 & 0.5 & - & 4.32 \\
\hline \multirow[t]{2}{*}{ Sub-watershed 6} & Stream no & 65 & 13 & 2 & 1 & - & - & \\
\hline & Stream length & 20 & 13 & 2.5 & 6 & - & - & 3.38 \\
\hline \multirow[t]{2}{*}{ Sub-watershed 7} & Stream no & 101 & 14 & 4 & 2 & 1 & - & \\
\hline & Stream length & 19 & 7.5 & 2 & 1.5 & 0.5 & - & 3.68 \\
\hline \multirow[t]{2}{*}{ Sub-watershed 8} & Stream no & 48 & 6 & 4 & 3 & 1 & - & \\
\hline & Stream length & 11 & 7 & 6 & 1 & 0.5 & - & 3.46 \\
\hline \multirow[t]{2}{*}{ Sub-watershed 9} & Stream no & 92 & 18 & 6 & 3 & 1 & - & \\
\hline & Stream length & 24 & 12 & 7 & 2 & 0.5 & - & 3.28 \\
\hline \multirow[t]{2}{*}{ Sub-watershed 10} & Stream no & 252 & 26 & 6 & 2 & 1 & - & \\
\hline & Stream length & 50 & 20 & 14 & 8 & 0.5 & - & 4.76 \\
\hline \multirow[t]{2}{*}{ Sub-watershed 11} & Stream no & 167 & 35 & 5 & 2 & 1 & - & \\
\hline & Stream length & 56 & 29 & 15 & 10 & 0.5 & - & 4.07 \\
\hline \multirow[t]{2}{*}{ Sub-watershed 12} & Stream no & 86 & 30 & 3 & 1 & - & - & \\
\hline & Stream length & 19 & 14 & 5 & 4 & - & - & 3.97 \\
\hline \multirow[t]{2}{*}{ Sub-watershed 13} & Stream no & 132 & 37 & 13 & 2 & 1 & - & \\
\hline & Stream length & 40 & 15 & 14 & 4 & 1 & - & 3.73 \\
\hline \multirow[t]{2}{*}{ Sub-watershed 14} & Stream no & 262 & 44 & 7 & 4 & 1 & & \\
\hline & Stream length & 74 & 36 & 13 & 17 & 1 & & 4.5 \\
\hline \multirow[t]{2}{*}{ Sub-watershed 15} & Stream no & 72 & 11 & 4 & 2 & 1 & & \\
\hline & Stream length & 29 & 10 & 4 & 4.5 & 1 & & 3.32 \\
\hline \multirow[t]{2}{*}{ Sub-watershed 16} & Stream no & 150 & 10 & 4 & 2 & 1 & & \\
\hline & Stream length & 26 & 13 & 7 & 2 & 1.5 & & 5.38 \\
\hline \multirow[t]{2}{*}{ Sub-watershed 17} & Stream no & 262 & 77 & 7 & 3 & 1 & & \\
\hline & Stream length & 75 & 40 & 18 & 15 & 0.5 & & 4.93 \\
\hline \multirow[t]{2}{*}{ Sub-watershed 18} & Stream no & 392 & 94 & 26 & 15 & 2 & 1 & \\
\hline & Stream length & 167 & 83 & 34 & 23 & 11 & 10 & 2.03 \\
\hline \multirow[t]{2}{*}{ Sub-watershed 19} & Stream no & 736 & 164 & 42 & 9 & 2 & 1 & \\
\hline & Stream length & 262 & 137 & 66 & 32 & 29 & 4 & 3.19 \\
\hline \multirow[t]{2}{*}{ Sub-watershed 20} & Stream no & 631 & 131 & 40 & 7 & 5 & 1 & \\
\hline & Stream length & 174 & 81 & 45 & 26 & 13 & 6 & 4.04 \\
\hline
\end{tabular}

\section{Stream frequency $\left(F_{s}\right)$}

$F_{\mathrm{S}}$ is the ratio (Eq. 4) of the total number of stream to the area of watershed (Horton 1945). The value of $F_{\mathrm{S}}$ varies from 3.91 to 9.99 and depends on the underlying bedrock of the drainage basin. $F_{\mathrm{s}}$ values are positively correlated with the $D_{\mathrm{d}}$ values of a catchment. This means that any increase in stream population is connected to that of drainage density.
For small and large drainage basins, $F_{\mathrm{s}}$ and $D_{\mathrm{d}}$ are not comparable. High $F_{\mathrm{s}}$ shows more percolation through slope materials and bedrock; thus, more groundwater potential exists. Reddy et al. (2004) stated that lower value of $F_{\mathrm{s}}$ indicates permeable subsurface material and low relief. The $F_{\mathrm{s}}$ value ranges from 3 (watershed 15) to 8.75 (watershed 17). $F_{\mathrm{s}}$ value is given in Table 5 . 
Table 5 Aerial aspect parameters value of watersheds

\begin{tabular}{|c|c|c|c|c|c|c|c|c|c|}
\hline Sub-watershed & $\begin{array}{l}\text { Drainage } \\
\text { density } \\
\left(D_{\mathrm{d}}\right)\end{array}$ & $\begin{array}{l}\text { Stream } \\
\text { frequency } \\
\left(F_{\mathrm{s}}\right)\end{array}$ & Texture ratio $(T)$ & $\begin{array}{l}\text { Elonga- } \\
\text { tion ratio } \\
\left(R_{\mathrm{e}}\right)\end{array}$ & $\begin{array}{l}\text { Circular- } \\
\text { ity ratio } \\
\left(R_{\mathrm{c}}\right)\end{array}$ & Form factor $\left(R_{\mathrm{f}}\right)$ & $\begin{array}{l}\text { Shape } \\
\text { factor } \\
\left(B_{\mathrm{S}}\right)\end{array}$ & $\begin{array}{l}\text { Compactness } \\
\text { constant }\left(C_{\mathrm{c}}\right)\end{array}$ & $\begin{array}{l}\text { Length of over- } \\
\text { land flow }\left(L_{\mathrm{o}}\right)\end{array}$ \\
\hline 1 & 1.65 & 3.52 & 5.28 & 0.69 & 1.05 & 0.37 & 2.7 & 0.04 & 0.30 \\
\hline 2 & 1.98 & 6.27 & 7.76 & 0.67 & 0.74 & 0.37 & 2.68 & 0.05 & 0.25 \\
\hline 3 & 1.67 & 4.17 & 5.95 & 0.68 & 0.85 & 0.36 & 2.73 & 0.04 & 0.30 \\
\hline 4 & 2.37 & 4.59 & 4.98 & 0.66 & 0.29 & 0.34 & 2.94 & 0.04 & 0.21 \\
\hline 5 & 2.11 & 6.55 & 7.2 & 0.67 & 0.69 & 0.38 & 2.62 & 0.06 & 0.24 \\
\hline 6 & 1.73 & 3.38 & 4.5 & 0.69 & 0.93 & 0.38 & 2.65 & 0.05 & 0.29 \\
\hline 7 & 1.22 & 4.88 & 6.78 & 0.69 & 0.97 & 0.37 & 2.67 & 0.05 & 0.41 \\
\hline 8 & 1.34 & 3.26 & 5.17 & 0.70 & 1.65 & 0.39 & 2.57 & 0.05 & 0.37 \\
\hline 9 & 1.75 & 4.62 & 6.32 & 0.69 & 0.90 & 0.37 & 2.68 & 0.05 & 0.29 \\
\hline 10 & 2.43 & 7.55 & 7.36 & 0.67 & 0.31 & 0.35 & 2.82 & 0.05 & 0.20 \\
\hline 11 & 2.83 & 5.38 & 4.47 & 0.67 & 0.22 & 0.35 & 2.83 & 0.05 & 0.18 \\
\hline 12 & 1.68 & 4.80 & 6.32 & 0.69 & 0.87 & 0.37 & 2.67 & 0.05 & 0.30 \\
\hline 13 & 2.18 & 5.44 & 5.78 & 0.68 & 0.42 & 0.36 & 2.78 & 0.05 & 0.23 \\
\hline 14 & 2.88 & 6.49 & 5.39 & 0.66 & 0.18 & 0.34 & 2.92 & 0.04 & 0.17 \\
\hline 15 & 1.62 & 3.00 & 4.5 & 0.68 & 0.94 & 0.36 & 2.73 & 0.04 & 0.31 \\
\hline 16 & 1.98 & 6.68 & 9.28 & 0.69 & 0.97 & 0.37 & 2.67 & 0.05 & 0.25 \\
\hline 17 & 3.71 & 8.75 & 5.74 & 0.67 & 0.13 & 0.35 & 2.84 & 0.05 & 0.13 \\
\hline 18 & 2.58 & 4.27 & 6.88 & 0.12 & 0.26 & 0.30 & 3.32 & 0.02 & 0.19 \\
\hline 19 & 2.47 & 4.44 & 8.83 & 0.10 & 0.23 & 0.28 & 3.57 & 0.01 & 0.20 \\
\hline 20 & 2.45 & 5.78 & 11.32 & 0.13 & 0.34 & 0.30 & 3.38 & 0.02 & 0.20 \\
\hline
\end{tabular}

\section{Texture ratio $(T)$}

$T$ is the ratio of the total number of the stream of a particular order to the watershed perimeter (Eq. 5). The parameter is considered as significant factor in the drainage basin morphometric study and depends on lithology, surface materials, infiltration capacity and the relief of an area (Altaf et al. 2013). The value $T$ for the proposed area is given in Table 5 .

\section{Elongation ratio $\left(R_{\mathrm{e}}\right)$}

According to Schumm (1956), $R_{\mathrm{e}}$ is the ratio of diameter of a circle having an equal area of the basin to the maximum basin length (Eq. 6) and helps to understand the hydrological nature of a drainage basin. The value of $R_{\mathrm{e}}$ varies from 0.6 to 1.0 depending on climate and geology. For very low relief, $R_{\mathrm{e}}$ value is close to 1.0, and for high relief and steep slope $R_{\mathrm{e}}$ value ranges from 0.6 to 0.8 (Strahler 1964). Runoff is high in a circular basin compared to the elongated basin (Singh and Singh 1997). Higher $R_{\mathrm{e}}$ indicates a high percolation rate, low runoff and limited soil erosion (Reddy et al. 2004). The value of $R_{\mathrm{e}}$ is given in Table 5 .

\section{Compactness constant $\left(C_{c}\right)$}

$C_{\mathrm{c}}$ was elaborated by Gravelius (1914) and also known as Gravelius index (GI). It is the ratio of watershed perimeter to the circumference of the circular area equal to the watershed area (Eq. 10). The catchment is a perfect circle when $C_{\mathrm{c}}$ is one and takes a short time for the concentration of peak flow, for $C_{\mathrm{c}}$ value of 1.28 watersheds are square-shaped, and for $C_{\mathrm{c}}$ value greater than 3.0 watersheds are varying in their shape (Zavoianu 1985; Altaf et al. 2013). $C_{\mathrm{c}}$ parameter of a watershed is independent of size, but dependent on the slope (Horton 1945). $C_{\mathrm{c}}$ values of the watersheds are illustrated in Table 5.

\section{Length of overland flow $\left(L_{0}\right)$}

According to Miller (1953), $L_{\mathrm{o}}$ is calculated as half of the $D_{\mathrm{d}}$ (Eq. 11). Overland flow and runoff are two different terms. Overland flow is the water after rainfall that moves over the land to reach into the channels, and runoff is the water that moves through the channel to reach a particular outlet. The overland flow is dominant in the smaller watershed. Table 5 describes the $L_{\mathrm{o}}$ value for all watersheds. 


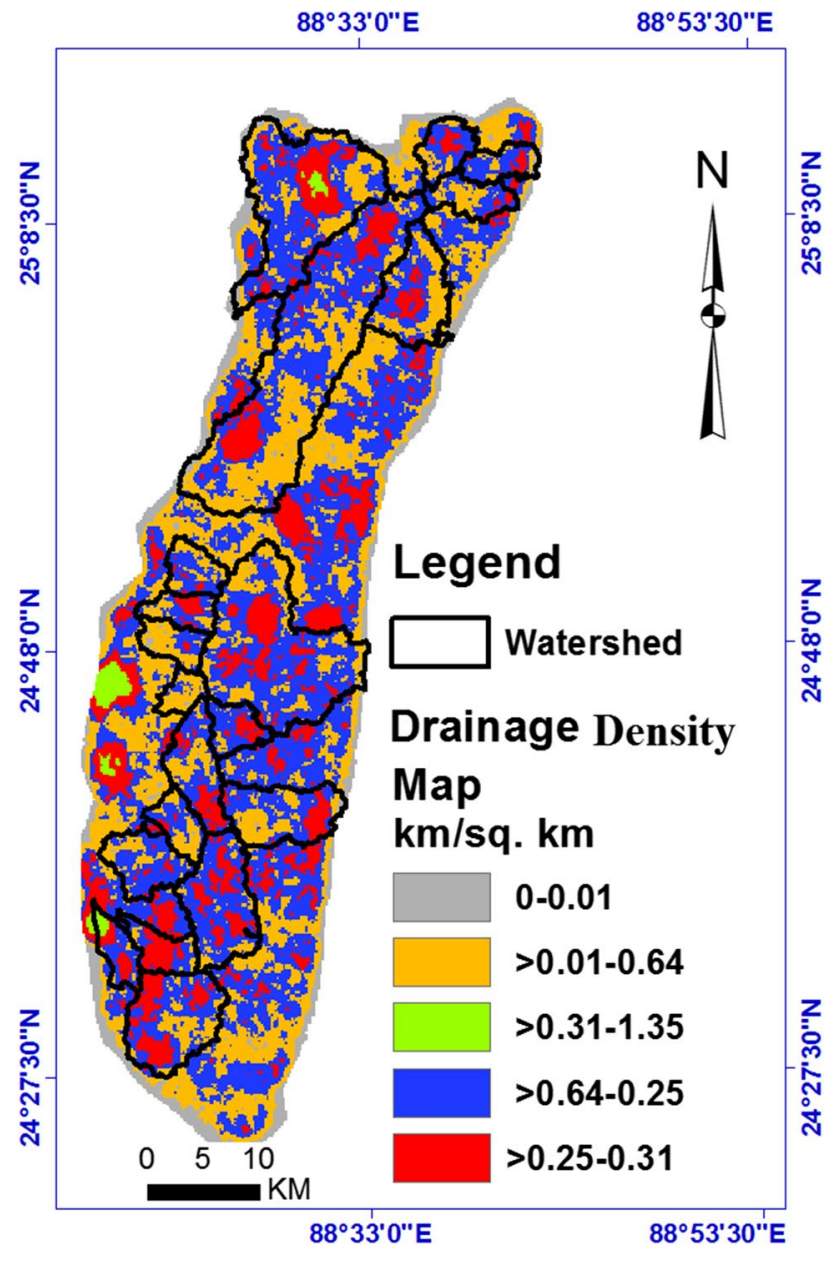

Fig. 8 Drainage density of the proposed area

\section{Relief ratio $\left(R_{\mathrm{h}}\right)$}

According to Schumm (1956), $R_{\mathrm{h}}$ is the ratio of the maximum relief of a basin to the distance along the longest dimension of the basin (Eq. 12). Difference between the highest and lowest elevation points is termed as the total relief. Low relief ratio occurred for the resistant basement and flat sloping area. $R_{\mathrm{h}}$ normally rises for decreasing drainage area and size. $R_{\mathrm{h}}$ value for each watershed is given in Table 6.

\section{Average slope $\left(S_{a}\right)$}

$S_{\mathrm{a}}$ is related to the erosion of the watershed. The researcher proved that the more the percentage of slopes are, the more the erosion if other factors remain unchanged. The average slope varies from 1.62 (watershed 16) to 2.13 (watershed 5). $S_{\mathrm{a}}$ value for all watersheds is given in Table 6 .

\section{Relative relief $\left(R_{\mathrm{r}}\right)$}

$R_{\mathrm{r}}$ is the ratio of the maximum watershed relief to the perimeter of the watershed. Table 6 shows the relative relief values for all watersheds. Relative relief values range from 0.001 to 0.003 for the proposed area. Figure 9 describes the relative relief map of the study area.

\section{Ruggedness number $\left(R_{\mathrm{N}}\right)$}

Table 6 shows the ruggedness number of the watersheds, and Eq. 13 has been used to calculate the $R_{\mathrm{N}}$. The ruggedness number varies from 0.04 (watershed 7 , watershed 8 and watershed 15) to 0.13 (watershed 19). The watershed has the overall low roughness which shows the structural complexity of the terrain in association with relief and drainage density. It also implies that the area is less susceptible to erosion.

\section{Hypsometric integral (HI)}

HI refers to the relation of the cross-sectional area along the horizontal direction to the elevation (Langbein 1947). HI shows the erosional stages of the watershed, and the volume of mass remains above the base. Harlin (1978) derives cumulative probability distribution for detection hypsometric curve and various statistical parameters to quantify HI. HI, an analysis, was carried out using the polynomial function, viz. second or third grade (Harlin 1978), and has been derived using Eq. 14. HI values for all watersheds are given in Table 6 .

HI value $\geq 0.60$ shows youth stage/convex upward curves, and basin is highly susceptible to erosion and land sliding, when $0.30 \leq \mathrm{HI} \leq 0.60$, basin is the mature stage or equilibrium/S-shaped, and when $\mathrm{HI}$ value $\leq 0.30$, basin is old (monadnock) or peneplain stage (concave upward curve).

\section{Inter-correlation among geomorphic parameters}

Inter-correlation among geomorphic parameters was carried out using SPSS 25 software. Meshram and Sharma (2015) have described that when correlation coefficient value $>0.9$, the parameter is strongly correlated, when correlation coefficient value $>0.75$, the parameter has good correlation, when correlation coefficient value $>0.6$, the parameter is moderately correlated, and when correlation coefficient value is 0.6 to $<0.6$, the parameter has poor correlation. Table 7 reveals that elements among $D_{\mathrm{d}}$ to $L_{\mathrm{o}}$ and $B_{\mathrm{S}}$ to $R_{\mathrm{f}}, R_{\mathrm{e}}$ and $C_{\mathrm{c}}$ are strongly correlated. Besides $R_{\mathrm{h}}$ to $R_{\mathrm{r}}, B_{\mathrm{S}}, R_{\mathrm{c}}, R_{\mathrm{f}} ; R_{\mathrm{r}}$ to $R_{\mathrm{c}}, L_{\mathrm{o}}$; $R_{\mathrm{N}}$ to $D_{\mathrm{d}}, B_{\mathrm{S}}, R_{\mathrm{c}}, R_{\mathrm{f}}, L_{\mathrm{o}}$; and $D_{\mathrm{d}}$ to $R_{\mathrm{c}}$ have good correlation, 
Table 6 Relief aspect of watersheds

\begin{tabular}{|c|c|c|c|c|c|c|c|c|}
\hline WS no. & $\begin{array}{l}\text { Maximum } \\
\text { elevation }\end{array}$ & $\begin{array}{l}\text { Minimum } \\
\text { elevation }\end{array}$ & $\begin{array}{l}\text { Total relief or } \\
\text { basin relief }\end{array}$ & Relief ratio $R_{\mathrm{h}}$ & $\begin{array}{l}\text { Average } \\
\text { slope } S_{\mathrm{a}}\end{array}$ & Relative relief $R_{\mathrm{r}}$ & $\begin{array}{l}\text { Ruggedness } \\
\text { number }\left(R_{\mathrm{N}}\right)\end{array}$ & $\mathrm{HI}$ \\
\hline 1 & 54 & 19 & 35 & 0.004 & 2.12 & 0.002 & 0.06 & 0.501 \\
\hline 2 & 51 & 25 & 26 & 0.003 & 1.98 & 0.001 & 0.05 & 0.527 \\
\hline 3 & 53 & 19 & 34 & 0.004 & 2.07 & 0.002 & 0.06 & 0.506 \\
\hline 4 & 54 & 16 & 38 & 0.003 & 1.94 & 0.001 & 0.09 & 0.492 \\
\hline 5 & 53 & 18 & 35 & 0.005 & 2.13 & 0.002 & 0.07 & 0.482 \\
\hline 6 & 54 & 20 & 34 & 0.004 & 2.11 & 0.002 & 0.06 & 0.533 \\
\hline 7 & 55 & 22 & 33 & 0.004 & 2.04 & 0.002 & 0.04 & 0.507 \\
\hline 8 & 55 & 23 & 32 & 0.005 & 1.93 & 0.003 & 0.04 & 0.501 \\
\hline 9 & 53 & 26 & 27 & 0.003 & 1.86 & 0.001 & 0.05 & 0.487 \\
\hline 10 & 55 & 26 & 29 & 0.003 & 1.84 & 0.001 & 0.07 & 0.492 \\
\hline 11 & 54 & 18 & 36 & 0.003 & 1.68 & 0.001 & 0.10 & 0.459 \\
\hline 12 & 52 & 22 & 30 & 0.004 & 1.63 & 0.002 & 0.05 & 0.507 \\
\hline 13 & 50 & 22 & 28 & 0.003 & 1.73 & 0.001 & 0.06 & 0.512 \\
\hline 14 & 54 & 21 & 33 & 0.003 & 1.68 & 0.001 & 0.09 & 0.502 \\
\hline 15 & 49 & 24 & 25 & 0.003 & 1.85 & 0.001 & 0.04 & 0.578 \\
\hline 16 & 46 & 12 & 34 & 0.004 & 1.62 & 0.002 & 0.07 & 0.505 \\
\hline 17 & 48 & 21 & 27 & 0.002 & 2.09 & 0.001 & 0.10 & 0.523 \\
\hline 18 & 47 & 5 & 42 & 0.002 & 2.03 & 0.001 & 0.11 & 0.532 \\
\hline 19 & 54 & 0 & 54 & 0.002 & 1.96 & 0.001 & 0.13 & 0.556 \\
\hline 20 & 54 & 15 & 39 & 0.002 & 1.90 & 0.001 & 0.09 & 0.449 \\
\hline
\end{tabular}

and $R_{\mathrm{h}}$ to $R_{\mathrm{N}}, D_{\mathrm{d}}, R_{\mathrm{e}}, L_{\mathrm{o}}, C_{\mathrm{c}} ; R_{\mathrm{r}}$ to $D_{\mathrm{d}}, R_{\mathrm{f}} ; R_{\mathrm{N}}$ to $R_{\mathrm{e}}, C_{\mathrm{c}} ; R_{\mathrm{b}}$ to $F_{\mathrm{s}} ; D_{\mathrm{d}}$ to $F_{\mathrm{s}} ; F_{\mathrm{s}}$ to $L_{\mathrm{o}} ; B_{\mathrm{S}}$ to $R_{\mathrm{c}} ; R_{\mathrm{c}}$ to $R_{\mathrm{f}}, L_{\mathrm{o}} ; R_{\mathrm{e}}$ to $T$ have a moderate correlation. Several elements have no correlation among the other elements. Therefore, it is very difficult to carry a correlation among elements (Meshram and Sharma 2015). Therefore, principal component analysis has been carried out to the inter-correlation matrix for grouping the components.

\section{Principal component analysis}

The principal component analysis method was applied to the inter-correlation matrix to get the first-factor loading matrix and afterward rotated the loading matrix using the orthogonal transformation. Discussion of principal component analysis has been given in the following section.

\section{First-factor loading matrix}

Table 8 shows that the eigenvalue of the first 3 components is greater than 1 and the total cumulative value is $81.02 \%$. Table 9 shows that the first component is strongly correlated with $B_{\mathrm{s}}$ and $R_{\mathrm{f}}(>0.9)$, good correlation is existing for $R_{\mathrm{h}}$, $R_{\mathrm{r}}, R_{\mathrm{N}}, D_{\mathrm{d}}, R_{\mathrm{c}}, R_{\mathrm{e}}$ and $L_{\mathrm{o}}(>0.75)$, and moderate correlation exists for $C_{\mathrm{c}}(>0.6)$. The second component is good for correlation with $R_{\mathrm{b}}$ and $F_{\mathrm{s}}$ and moderate correlation with $C_{\mathrm{c}}$.
The third component is good for correlation with $T$. From the above result, it is found that $S_{\mathrm{a}}$ and HI have no correlation with any component. Therefore, some components have strong correlation, some have moderate correlation, some components contain good correlation, and some components have no correlation. In this stage, it is not possible to identify significant component for correlation. Therefore, it is important to rotate the first-factor loading matrix to get a reliable correlation.

\section{Rotation of first-factor loading matrix}

Rotated factor loading matrix from the first-factor loading matrix was obtained by post-multiplying the transformation matrix with the selected component. Table 10 gives the result of the rotation matrix. Table 10 shows first PCA component values $D_{\mathrm{d}}$ and $R_{\mathrm{c}}$ have a strong correlation, $R_{\mathrm{h}}, R_{\mathrm{r}}$, $R_{\mathrm{b}}$ and $L_{\mathrm{o}}$ have good correlation, and $R_{\mathrm{f}}$ has a moderate correlation. The second component shows that $R_{\mathrm{e}}$ has a strong correlation, $B_{\mathrm{s}}, R_{\mathrm{f}}, T$ and $C_{\mathrm{c}}$ have good correlation, and $R_{\mathrm{f}}$ has moderate correlation. The third component has a good correlation with $R_{\mathrm{b}}$ and $F_{\mathrm{s}}$ and moderate correlation with HI and $S_{\mathrm{a}}$. Therefore, $D_{\mathrm{d}}, R_{\mathrm{c}}, R_{\mathrm{e}}$ and $R_{\mathrm{b}}$ are the most important factors that can be taken for further priority measurement for erosion and water conservation measurement. 


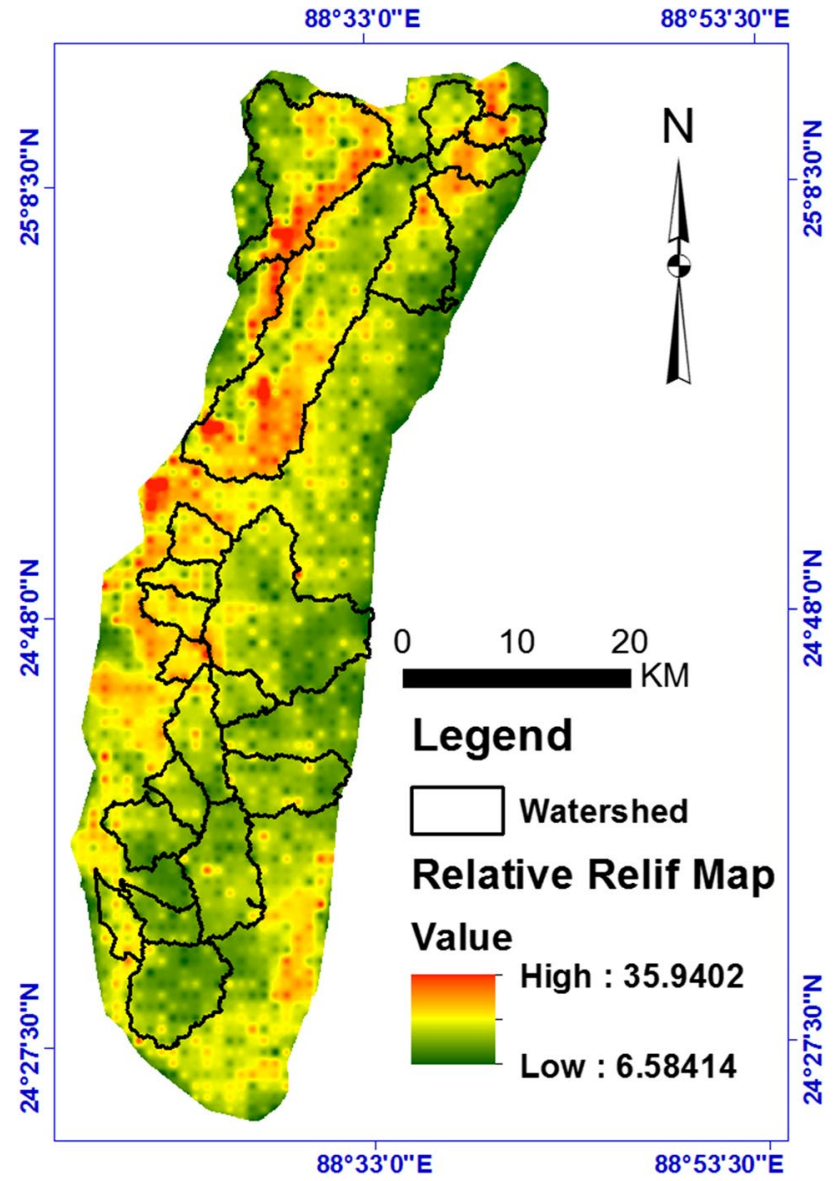

Fig. 9 Relative relief map of the proposed area

\section{Comparison of two approaches to prioritization of sub-watersheds for soil and water conservation}

According to Nooka et al. (2005), liner features are directly related to erosion of the soil and the high value of linear feature reflects that the area is more erosive. Similarly, the relief feature has an influence on erosion. Compound parameters $\left(C_{\mathrm{P}}\right)$ are produced by summing all the ranks of linear, shape and relief parameters and then dividing by the number of total parameters, as provided in Table 11. PCAbased analyses results (Table 10) reveal that parameters (viz. $R_{\mathrm{c}}, R_{\mathrm{e}}$ and $R_{\mathrm{b}}$ ) that have a strong correlation later are used for watershed prioritization after calculating the compound parameter $\left(C_{\mathrm{p}}\right)$ and priority rank $\left(R_{\mathrm{p}}\right)$ values (Table 12$)$. The highest prioritized rank $\left(R_{\mathrm{P}}\right)$ was assigned to the watershed having the lowest compound parameters $\left(C_{\mathrm{p}}\right)$ values. The $C_{\mathrm{p}}$ values ranges from 8.47 (Watershed 2) to 12.87 (watershed 11). Final priority $R_{\mathrm{p}}$ that has been taken for watershed 2 is one as higher rank, and for watershed $11, R_{\mathrm{p}}$ value has been taken twenty as a lower rank. Figure 10 shows the completed map for the water and soil conservation practice.

\section{Conclusion}

GIS- and RS-based morphometric studies were conducted to select watershed for water and soil conservation measures at the Plio-Pleistocene elevated tract in Bangladesh. Sixteen areal, linear and relief parameters were chosen for twenty watersheds, where seventeen are fifth order and three are sixth order. Principal component analysis, compound parameters detection and priority ranking were carried on the morphometric parameters for reduction in the elements from

Table 7 Inter-correlation matrix among geomorphic parameters of the study area

\begin{tabular}{|c|c|c|c|c|c|c|c|c|c|c|c|c|c|c|c|}
\hline & h & r & $R_{N}$ & $R_{\mathrm{b}}$ & $D_{\mathrm{d}}$ & $F_{\mathrm{s}}$ & $B_{\mathrm{s}}$ & $R_{\mathrm{c}}$ & $R_{\mathrm{f}}$ & $R_{\mathrm{e}}$ & $T$ & $L_{\mathrm{o}}$ & $C_{\mathrm{c}}$ & $S_{\mathrm{a}}$ & HI \\
\hline h & 00 & 88 & 7 & 5 & 8 & 8 & 7 & & 81 & 63 & 3 & 0.69 & 0.64 & .09 & -0 \\
\hline$R_{\mathrm{r}}$ & 0 & 0 & -0.52 & 1 & 0.65 & 0.36 & -0.54 & & 61 & 36 & & 71 & 37 & 0 & \\
\hline $\mathrm{N}$ & 0.67 & 0. & 0 & 0.09 & & & & 1 & 0.83 & 8 & 7 & & & 1 & 05 \\
\hline$b$ & 0 & 0.01 & 0.09 & 1. & & 74 & 0.36 & - & 2 & 0.47 & 3 & 5 & 0.49 & 26 & .31 \\
\hline$P_{d}$ & 0.68 & -0.65 & 17 & 0.26 & 1.00 & 0.68 & ty & - & - & 0 & 0.09 & 5 & 22 & 10 & .13 \\
\hline$F_{\mathrm{s}}$ & 0.28 & -0.36 & 0.31 & 0.74 & 0.00 & 1.00 & 0.03 & -0 & - & 0.08 & ו & - & 0.26 & 17 & .30 \\
\hline$B_{\mathrm{s}}$ & -0.77 & -0.54 & 0.82 & -0.36 & 0.47 & 0.03 & 1.00 & -0.65 & -0.99 & -0.94 & 0.01 & -0.55 & -0.92 & .03 & 0.07 \\
\hline$R_{\mathrm{c}}$ & 0.77 & 0.82 & 0.81 & -0.09 & 0.87 & 0.55 & -0.65 & 1.00 & 0.7 & 0.44 & - & 0.89 & 9 & 3 & 0.11 \\
\hline$R_{\mathrm{f}}$ & 0.81 & 0.61 & -0.83 & 0.32 & -0.53 & -0.08 & - & 0.7 & 1.00 & 0.91 & - & 0.59 & 0.91 & 0.02 & -0.08 \\
\hline$R_{\mathrm{e}}$ & 0.63 & 0.36 & -0.68 & 0.47 & -0.30 & 0.08 & -0.94 & 0.44 & 0.91 & 1.00 & -0.60 & 0.37 & 0.91 & -0.14 & -0.08 \\
\hline$T$ & -0.28 & -0.14 & 0.27 & 0.23 & 0.09 & 0.37 & 0.51 & -0.18 & -0.48 & -0.61 & 1.00 & -0.19 & -0.42 & -0.07 & -0.23 \\
\hline$L_{\mathrm{o}}$ & 0.69 & 0.71 & -0.81 & -0.25 & -0.93 & -0.62 & -0.55 & 9 & .59 & 0.37 & -0.19 & 1.00 & 0.29 & 0.17 & 0.14 \\
\hline$C_{\mathrm{c}}$ & 0.64 & 0.37 & -0.63 & 0.49 & -0.22 & 0.26 & -0.92 & 9 & 91 & 0.91 & -0.42 & 0.29 & .00 & -0.11 & -0.22 \\
\hline $\mathrm{a}$ & 0.09 & 0.20 & 0.01 & -0.26 & -0.10 & -0.11 & 0.03 & 0.13 & 0.02 & -0.14 & -0.07 & 0.17 & -0.11 & 1.00 & 0.19 \\
\hline HI & 0.16 & 0.08 & -0.05 & -0.31 & -0.13 & -0.30 & 0.07 & 0.11 & -0.08 & -0.08 & -0.23 & 0.14 & -0.22 & 0.19 & 1.00 \\
\hline
\end{tabular}


Table 8 Total variance of the watersheds

\begin{tabular}{|c|c|c|c|c|c|c|c|c|c|}
\hline \multirow[t]{2}{*}{ Component } & \multicolumn{3}{|c|}{ Initial eigenvalues } & \multicolumn{3}{|c|}{ Extraction sums of squared loadings } & \multicolumn{3}{|c|}{ Rotation sums of squared loadings } \\
\hline & Total & $\%$ of variance & Cumulative (\%) & Total & $\%$ of variance & Cumulative (\%) & Total & $\%$ of variance & Cumulative (\%) \\
\hline 1 & 7.39 & 49.30 & 49.30 & 7.39 & 49.30 & 49.30 & 5.29 & 35.24 & 35.24 \\
\hline 2 & 3.25 & 21.65 & 70.95 & 3.25 & 21.65 & 70.95 & 4.32 & 28.79 & 64.03 \\
\hline 3 & 1.51 & 10.07 & 81.02 & 1.51 & 10.07 & 81.02 & 2.55 & 16.99 & 81.02 \\
\hline 4 & 0.99 & 6.60 & 87.62 & & & & & & \\
\hline 5 & 0.81 & 5.42 & 93.04 & & & & & & \\
\hline 6 & 0.51 & 3.40 & 96.44 & & & & & & \\
\hline 7 & 0.20 & 1.36 & 97.80 & & & & & & \\
\hline 8 & 0.14 & 0.92 & 98.71 & & & & & & \\
\hline 9 & 0.10 & 0.68 & 99.40 & & & & & & \\
\hline 10 & 0.05 & 0.31 & 99.70 & & & & & & \\
\hline 11 & 0.02 & 0.13 & 99.83 & & & & & & \\
\hline 12 & 0.01 & 0.09 & 99.92 & & & & & & \\
\hline 13 & 0.01 & 0.04 & 99.96 & & & & & & \\
\hline 14 & 0.00 & 0.03 & 99.99 & & & & & & \\
\hline 15 & 0.00 & 0.01 & 100.00 & & & & & & \\
\hline
\end{tabular}

Table 9 Unrotated matrix

\begin{tabular}{lrrr}
\hline Parameters & \multicolumn{2}{l}{ Component } & \\
\cline { 2 - 4 } & \multicolumn{1}{c}{1} & \multicolumn{1}{l}{3} \\
\hline$R_{\mathrm{h}}$ & 0.890 & 0.015 & 0.211 \\
$R_{\mathrm{r}}$ & 0.759 & -0.217 & 0.346 \\
$R_{\mathrm{N}}$ & -0.896 & 0.035 & -0.031 \\
$R_{\mathrm{b}}$ & 0.111 & 0.844 & 0.293 \\
$D_{\mathrm{d}}$ & -0.773 & 0.511 & -0.222 \\
$F_{\mathrm{S}}$ & -0.351 & 0.840 & 0.191 \\
$B_{\mathrm{S}}$ & -0.912 & -0.365 & 0.150 \\
$R_{\mathrm{c}}$ & 0.872 & -0.343 & 0.206 \\
$R_{\mathrm{f}}$ & 0.936 & 0.306 & -0.098 \\
$R_{\mathrm{e}}$ & 0.784 & 0.515 & -0.297 \\
$T$ & -0.436 & -0.020 & 0.825 \\
$L_{\mathrm{o}}$ & 0.818 & -0.471 & 0.156 \\
$C_{\mathrm{c}}$ & 0.737 & 0.615 & -0.132 \\
$S_{\mathrm{a}}$ & 0.065 & -0.356 & -0.087 \\
$\mathrm{HI}$ & -0.003 & -0.429 & -0.529 \\
\hline
\end{tabular}

more parameters through inter-correlation matrix and then unrotated matrix and rotated matrices. The watershed that is suitable for water and soil conservation has been taken one as priority ranking $\left(R_{\mathrm{p}}\right)$, and the corresponding compound parameter $\left(C_{\mathrm{p}}\right)$ value is 7.75 . A strongly correlated component from PCA was later used for the compound parameter and for final priority detection. The first three components have an eigenvalue greater than one, and the cumulative value is $81.02 \%$.

The findings that can be concluded are as follows:
Table 10 Rotated matrix

\begin{tabular}{lrrr}
\hline Parameters & \multicolumn{2}{c}{ Component } \\
\cline { 2 - 4 } & \multicolumn{1}{c}{ 1 } & \multicolumn{1}{c}{3} \\
\hline$R_{\mathrm{h}}$ & 0.790 & 0.448 & 0.115 \\
$R_{\mathrm{r}}$ & 0.845 & 0.168 & 0.026 \\
$R_{\mathrm{N}}$ & -0.722 & -0.531 & 0.039 \\
$R_{\mathrm{b}}$ & -0.088 & 0.330 & 0.833 \\
$D_{\mathrm{d}}$ & -0.906 & -0.099 & 0.280 \\
$F_{\mathrm{S}}$ & -0.496 & 0.095 & 0.781 \\
$B_{\mathrm{S}}$ & -0.490 & -0.851 & -0.153 \\
$R_{\mathrm{c}}$ & 0.910 & 0.257 & -0.163 \\
$R_{\mathrm{f}}$ & 0.558 & 0.806 & 0.141 \\
$R_{\mathrm{e}}$ & 0.259 & 0.932 & 0.180 \\
$T$ & 0.087 & -0.766 & 0.525 \\
$L_{\mathrm{o}}$ & 0.892 & 0.187 & -0.292 \\
$C_{\mathrm{c}}$ & 0.268 & 0.857 & 0.363 \\
$S_{\mathrm{a}}$ & 0.142 & -0.090 & -0.732 \\
$\mathrm{HI}$ & -0.106 & 0.088 & -0.667 \\
\hline
\end{tabular}

- The whole work has been carried out using SRTM DEM used to extract morphometric parameters using GIS and RS.

- PCA analysis component showing that $D_{\mathrm{d}}, R_{\mathrm{c}}, R_{\mathrm{e}}$ and $R_{\mathrm{b}}$ parameters are strongly correlated that were later used for the final prioritization ranking. 
Table 11 Priorities of subwatersheds and theirs ranks

\begin{tabular}{lrrrrrrrrrrrrrrrrrr}
\hline Watershed no. $R_{\mathrm{b}}$ & $D_{\mathrm{d}}$ & $F_{\mathrm{s}}$ & $R_{\mathrm{c}}$ & $R_{\mathrm{f}}$ & $B_{\mathrm{s}}$ & $R_{\mathrm{e}}$ & $T$ & $L_{\mathrm{o}}$ & $C_{\mathrm{c}}$ & $R_{\mathrm{N}}$ & $R_{\mathrm{r}}$ & $R_{\mathrm{h}}$ & $S_{\mathrm{a}}$ & HI & $\begin{array}{l}\text { Compound } \\
\text { parameter } \\
\left(C_{\mathrm{p}}\right)\end{array}$ & $\begin{array}{l}\text { Final } \\
\text { priority } \\
\left(R_{\mathrm{p}}\right)\end{array}$ \\
\hline 1 & & & & & & & & & & & & & & & & & & \\
2 & 12 & 4 & 17 & 2 & 17 & 7 & 18 & 15 & 6 & 6 & 14 & 15 & 5 & 2 & 13 & 10.20 & 8 \\
3 & 3 & 9 & 6 & 10 & 12 & 9 & 9 & 4 & 10 & 13 & 17 & 2 & 10 & 8 & 5 & 8.47 & 1 \\
4 & 9 & 5 & 16 & 9 & 10 & 10 & 12 & 11 & 5 & 7 & 13 & 16 & 6 & 5 & 10 & 9.60 & 3 \\
5 & 11 & 13 & 13 & 15 & 5 & 17 & 5 & 17 & 13 & 5 & 5 & 8 & 15 & 10 & 15 & 11.13 & 16 \\
6 & 6 & 11 & 4 & 11 & 18 & 2 & 10 & 6 & 11 & 20 & 8 & 19 & 1 & 1 & 18 & 9.73 & 4 \\
7 & 16 & 7 & 18 & 6 & 19 & 3 & 19 & 18 & 8 & 15 & 11 & 17 & 7 & 3 & 3 & 11.33 & 17 \\
8 & 14 & 1 & 10 & 4 & 15 & 4 & 16 & 8 & 1 & 19 & 18 & 13 & 3 & 6 & 8 & 9.33 & 2 \\
9 & 15 & 2 & 19 & 1 & 20 & 1 & 20 & 16 & 2 & 18 & 19 & 20 & 2 & 11 & 14 & 12.00 & 19 \\
10 & 18 & 8 & 12 & 7 & 14 & 8 & 15 & 9 & 7 & 16 & 16 & 3 & 11 & 13 & 17 & 11.60 & 18 \\
11 & 4 & 14 & 2 & 14 & 8 & 13 & 8 & 5 & 16 & 11 & 10 & 5 & 13 & 15 & 16 & 10.27 & 10 \\
12 & 7 & 18 & 9 & 18 & 7 & 14 & 7 & 20 & 18 & 10 & 3 & 10 & 16 & 17 & 19 & 12.87 & 20 \\
13 & 10 & 6 & 11 & 8 & 13 & 5 & 14 & 10 & 4 & 17 & 15 & 14 & 4 & 19 & 9 & 10.60 & 12 \\
14 & 13 & 12 & 8 & 12 & 9 & 12 & 11 & 12 & 12 & 12 & 12 & 4 & 12 & 16 & 7 & 10.93 & 14 \\
15 & 5 & 19 & 5 & 19 & 4 & 16 & 4 & 14 & 19 & 4 & 6 & 7 & 14 & 18 & 12 & 11.07 & 15 \\
16 & 17 & 3 & 20 & 5 & 11 & 11 & 13 & 19 & 3 & 8 & 20 & 1 & 9 & 14 & 1 & 10.33 & 11 \\
17 & 1 & 10 & 3 & 3 & 16 & 6 & 17 & 2 & 9 & 14 & 9 & 18 & 8 & 20 & 11 & 9.80 & 5 \\
18 & 2 & 20 & 1 & 20 & 6 & 15 & 6 & 13 & 20 & 9 & 4 & 9 & 18 & 4 & 6 & 10.20 & 9 \\
19 & 20 & 17 & 15 & 16 & 2 & 18 & 2 & 7 & 17 & 2 & 2 & 11 & 19 & 7 & 4 & 10.60 & 13 \\
20 & 19 & 16 & 14 & 17 & 1 & 20 & 1 & 3 & 15 & 1 & 1 & 12 & 20 & 9 & 2 & 10.07 & 7 \\
\hline & 8 & 15 & 7 & 13 & 3 & 19 & 3 & 1 & 14 & 3 & 7 & 6 & 17 & 12 & 20 & 9.87 & 6 \\
\hline
\end{tabular}

Table 12 Priorities of subwatersheds and their rank using PCA-correlated elements

\begin{tabular}{|c|c|c|c|c|c|c|}
\hline Watershed no. & $R_{\mathrm{b}}$ & $D_{\mathrm{d}}$ & $R_{\mathrm{c}}$ & $R_{\mathrm{e}}$ & $\begin{array}{l}\text { Compound param- } \\
\text { eter }\left(C_{\mathrm{p}}\right)\end{array}$ & $\begin{array}{l}\text { Final } \\
\text { priority } \\
\left(R_{\mathrm{p}}\right) \\
\end{array}$ \\
\hline 1 & 12 & 4 & 2 & 18 & 9 & 5 \\
\hline 2 & 3 & 9 & 10 & 9 & 7.75 & 1 \\
\hline 3 & 9 & 5 & 9 & 12 & 8.75 & 3 \\
\hline 4 & 11 & 13 & 15 & 5 & 11 & 12 \\
\hline 5 & 6 & 11 & 11 & 10 & 9.5 & 6 \\
\hline 6 & 16 & 7 & 6 & 19 & 12 & 14 \\
\hline 7 & 14 & 1 & 4 & 16 & 8.75 & 4 \\
\hline 8 & 15 & 2 & 1 & 20 & 9.5 & 7 \\
\hline 9 & 18 & 8 & 7 & 15 & 12 & 15 \\
\hline 10 & 4 & 14 & 14 & 8 & 10 & 11 \\
\hline 11 & 7 & 18 & 18 & 7 & 12.5 & 18 \\
\hline 12 & 10 & 6 & 8 & 14 & 9.5 & 8 \\
\hline 13 & 13 & 12 & 12 & 11 & 12 & 16 \\
\hline 14 & 5 & 19 & 19 & 4 & 11.75 & 13 \\
\hline 15 & 17 & 3 & 5 & 13 & 9.5 & 9 \\
\hline 16 & 1 & 10 & 3 & 17 & 7.75 & 2 \\
\hline 17 & 2 & 20 & 20 & 6 & 12 & 17 \\
\hline 18 & 20 & 17 & 16 & 2 & 13.75 & 20 \\
\hline 19 & 19 & 16 & 17 & 1 & 13.25 & 19 \\
\hline 20 & 8 & 15 & 13 & 3 & 9.75 & 10 \\
\hline
\end{tabular}


Fig. 10 Final priority map

shows ranking for soil and water conservation practice

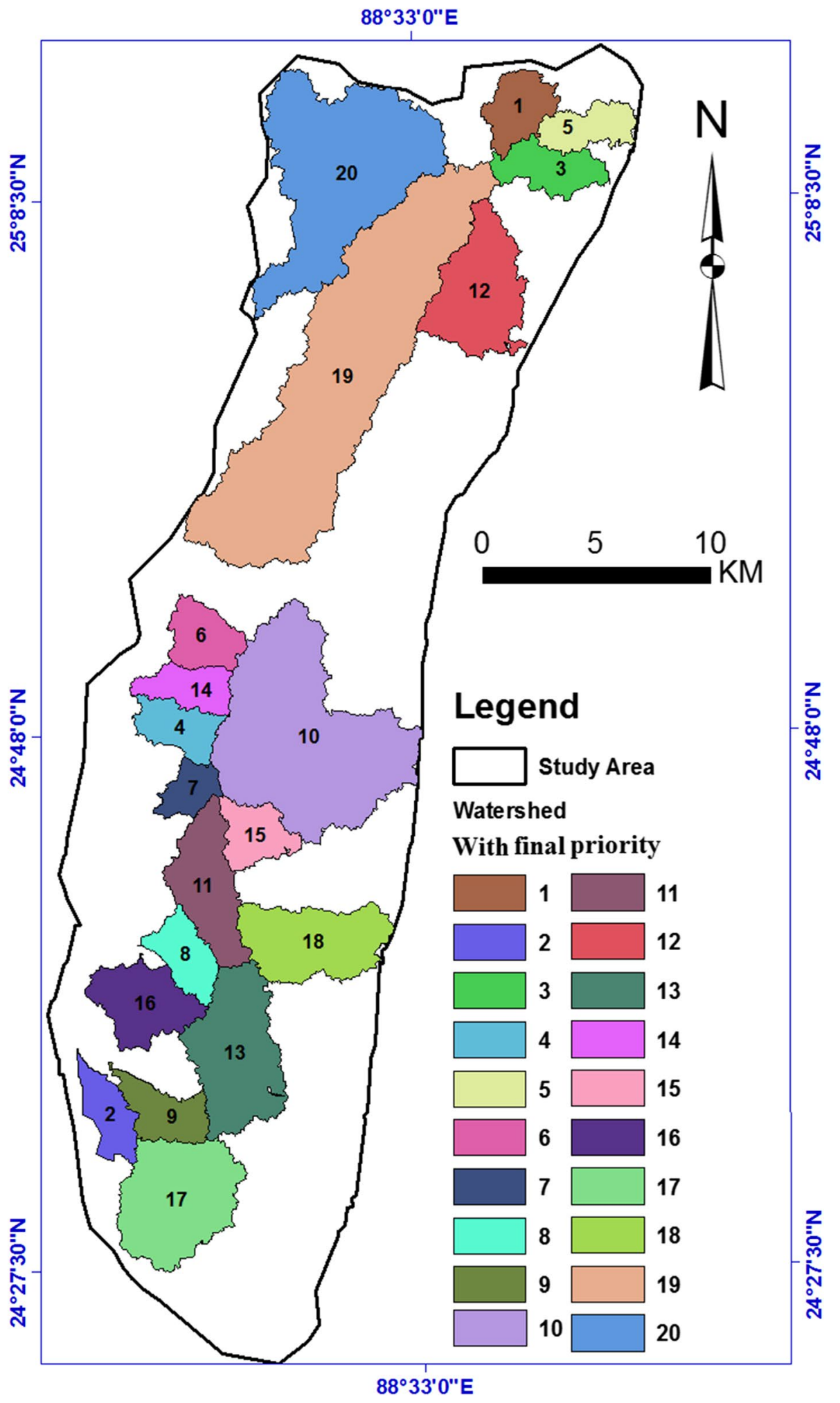


- GIS and RS methods are cost-effective, less time-consuming and reliable with recurrence analysis.

- Watershed 2 has high priority and watershed 11 has less priority for water and soil conservation.

The study area is drought-prone area, and impunity lies at the root of water conservation; therefore, the study will help to provide better understanding for the decisionmaker and use as a guideline for the hydro-geologist so that water resources are managed properly.

Funding The research work is not to collect a fund from any agency.

\section{Compliance with ethical standards}

Conflict of interest The research work is not associated with any government or private organization, so the conflict of interest is absent.

Ethical approval The data sets used for the research are publicly available, so there is no need for ethical approval. The manuscript is not submitted by any other journal before submission to this journal and further not submitted simultaneously to another journal.

Open Access This article is licensed under a Creative Commons Attribution 4.0 International License, which permits use, sharing, adaptation, distribution and reproduction in any medium or format, as long as you give appropriate credit to the original author(s) and the source, provide a link to the Creative Commons licence, and indicate if changes were made. The images or other third party material in this article are included in the article's Creative Commons licence, unless indicated otherwise in a credit line to the material. If material is not included in the article's Creative Commons licence and your intended use is not permitted by statutory regulation or exceeds the permitted use, you will need to obtain permission directly from the copyright holder. To view a copy of this licence, visit http://creativecommons.org/licenses/by/4.0/.

\section{References}

Agarwal CS (1998) Study of drainage pattern through aerial data in Naugarh area of Varanasi district, UP. J Indian Soc Remote Sens 26(4):169-175

Akinlalu AA, Adegbuyiro A, Adiat KAN, Akeredolu BE, Lateef WY (2017) Application of multi-criteria decision analysis in prediction of groundwater resources potential: a case of Oke-Ana, Ilesa Area Southwestern, Nigeria. NRIAG J Astron Geophys 6(1):184-200. https://doi.org/10.1016/j.nrjag.2017.03.001

Akram F, Rasul MG, Khan MMK, Amir MSII (2012) Automatic delineation of drainage networks and catchments using DEM data and GIS capabilities: a case study. In: 18th Australasian fluid mechanics conference Launceston, Australia

Al-Alawi SM, Abdul-Wahab SA, Bakheit CS (2008) Combining principal component regression and artificial neural networks for more accurate predictions of ground-level ozone. Environ Model Softw 23(4):396-403. https://doi.org/10.1016/j.envsoft.2006.08.007

Altaf F, Meraj G, Romshoo SA (2013) Morphometric analysis to infer hydrological behavior of Lidder watershed, Western Himalaya, India. Geogr J 13:1-14. https://doi.org/10.1155/2013/178021
Band LE (1986) Topographic partition of watersheds with digital elevation models. Water Resour Res 22(1):15-24. https://doi. org/10.1029/WR022i001p00015

Berhanu B, Melesse AM, Seleshi Y (2013) GIS-based hydrological zones and soil geodatabase of Ethiopia. CATENA 104:21-31. https://doi.org/10.1016/j.catena.2012.12.007

Bertolo F (2000) Catchment delineation and characterisation: a review. Space Applications Institute, Joint Research Centre, Ispra

Bouvier C, Cisneros L, Dominguez R, Laborde J-P, Lebel T (2003) Generating rainfall fields using principal components (PC) decomposition of the covariance matrix: a case study in Mexico City. J Hydrol 278(1-4):107-120. https://doi.org/10.1016/S0022 -1694(03)00122-7

Brown CE (1992) Use of principal-component, correlation and stepwise multiple regression analysis to investigate selected physical and hydraulic properties of carbonate-rock aquifers. J Hydrol 147(1-4):169-195. https://doi.org/10.1016/00221694(93)90080-S

Chopra R, Dhiman RD, Sharma PK (2005) Morphometric analysis of sub-watersheds in Gurdaspur district, Punjab using remote sensing and GIS techniques. J Indian Soc Remote Sens 33(4):531539. https://doi.org/10.1007/BF02990738

Choudhari PP, Nigam GK, Singh SK, Thakur S (2018) Morphometric based prioritization of watershed for groundwater potential of Mula river basin, Maharashtra, India. Geol Ecol Landsc 2(4):256-267. https://doi.org/10.1080/24749508.2018.1452482

Farhan Y, Anbar A, Al-Shaikh N, Mousa R (2017) Prioritization of semi-arid agricultural watershed using morphometric and principal component analysis, remote sensing, and GIS techniques, the Zerqa river watershed, Northern Jordan. Agric Sci 8(1):113-148. https://doi.org/10.4236/as.2017.81009

Gajbhiye S, Mishra SK, Pandey A (2014) Prioritizing erosion-prone area through morphometric analysis: an RS and GIS perspective. Appl Water Sci 4(1):51-61. https://doi.org/10.1007/s 1320 1-013-0129-7

Gayen S, Bhunia GS, Shit PK (2013) Morphometric analysis of Kangshabati-Darkeswar interfluves area in West Bengal, India using ASTER DEM and GIS techniques. Geol Geosci 2(4):110. https://doi.org/10.4172/2329-6755.1000133

Geological Survey of Bangladesh (GSB) (2001) Geological map of Bangladesh. Geological Survey of Bangladesh, Dhaka. https ://pubs.usgs.gov/of/1997/ofr-97-470/OF97-470H/BANGLA/ PLOT/BANG_GEO.PDF

Gravelius H (1914) Grundrifi der gesamten Gewässerkunde, Band 1: Flufikunde. In: Compendium of hydrology I, pp 265-278

Gurmessa TK, Bárdossy A (2009) A principal component regression approach to simulate the bed-evolution of reservoirs. J Hydrol 368(1-4):30-41. https://doi.org/10.1016/j.jhydrol.2009.01.033

Harlin JM (1978) Statistical moments of the hypsometric curve and its density function. Math Geol 10:59-72. https://doi.org/10.1007/ BF01033300

Horton RE (1932) Drainage basin characteristics. Am Geophys Union Trans 13:348-352

Horton RE (1945) Erosional development of streams and their drainage basins: hydrological approach to quantitative morphology. Geol Soc Am Bull 56:275-370. https://doi.org/10.1130/00167606(1945)56\%5b275:edosat\%5d2.0.co;2

Ibrahim-Bathis K, Ahmed SA (2016) Geospatial technology for delineating groundwater potential zones in Doddahalla watershed of Chitradurga district, India. Egypt J Remote Sens Space Sci 19(2):223-234. https://doi.org/10.1016/j.ejrs.2016.06.002

Jaiswal R, Thomas T, Galkate RV, Ghosh NC, Singh S (2014) Watershed prioritization using Saaty's AHP based decision support for soil conservation measures. Water Resour Manage 28:475-494. https://doi.org/10.1007/s11269-013-0494-x

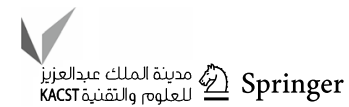


Javed A, Khanday MY, Rais S (2011) Watershed prioritization using morphometric and land use/land cover parameters: a remote sensing and GIS based approach. J Geol Soc India 78:63-75

Jha MK, Chowdhury A, Chowdary VM, Peiffer S (2007) Groundwater management and development by integrated RS and GIS: prospects and constraints. Water Resour Manag 21(2):427-467. https ://doi.org/10.1007/s11269-006-9024-4

Langbein WB (1947) Topographic characteristics of drainage basins. US Geol Surv Water Supply 986:157-159. https://doi. org/10.3133/wsp968C

Maathuis BHP, Wang L (2006) Digital elevation model based hydro-processing. Geocarto Int 21(1):21-26. https://doi. org/10.1080/10106040608542370

Magesh NS, Chandrasekar N, Soundranayagam JP (2011) Morphometric evaluation of Papanasam and Manimuthar watersheds, parts of Western Ghats, Tirunelveli district, Tamil Nadu, India: a GIS approach. Environ Earth Sci 64(2):373-381. https://doi. org/10.1007/s12665-010-0860-4

Magesh NS, Jitheshlal KV, Chandrasekar N, Jini KV (2012) GIS based morphometric evaluation of Chimmini and Mupily watersheds, parts of Western Ghats, Thrissur District, Kerala, India. Earth Sci Inform 5(2):111-121. https://doi.org/10.1007/s12145-012-0101-3

Mark DM (1984) Automatic detection of drainage networks from digital elevation models. Cartographica 21:168-178

Markose VJ, Dinesh AC, Jayappa KS (2014) Quantitative analysis of morphometric parameters of Kali river basin, southern India, using bearing azimuth and drainage (bAd) calculator and GIS. Environ Earth Sci 72(8):2887-2903. https://doi.org/10.1007/s12665-014-3193-x

Marks D, Dozier J, Frew J (1984) Automated basin delineation from digital elevation data. Geo-Processing 2:299-311

McGarry D (2006) A methodology of visual-soil field assessment tool to support, enhance, and contribute to the LADA program. Food and Agriculture Organization, Rome

Meshram SG, Sharma SK (2015) Prioritization of watershed through morphometric parameters: a PCA-based approach. Appl Water Sci 7(3):1505-1519. https://doi.org/10.1007/s13201-015-0332-9

Meshram SG, Sharma SK (2018) Application of principal component analysis for grouping of morphometric parameters and prioritization of watershed. Hydrol Model Water Sci Technol Libr 81:447458. https://doi.org/10.1007/978-981-10-5801-1_31

Miller VC (1953) A quantitative geomorphic study of drainage basin characteristics in the Clinch mountain area, Virginia and Tennesses. Department of Navy, Office of Naval Research, Technical Report 3, Project NR 389-042, Washington DC

Mishra N, Satyanarayana T (1988) Parameter grouping - a prelude to hydrologic modeling. Indian J Power River Val Dev 256-260

Moore ID, Grayson RB, Ladson AR (1991) Digital terrain modeling: a review of hydrological, geomorphologic and biological applications. Hydrol Process 5(1):3-30. https://doi.org/10.1002/ hyp.3360050103

Nag SK (1998) Morphometric analysis using remote sensing techniques in the Chaka sub-basin Purulia district, West Bengal. J Indian Soc Remote Sens 26(1):69-76. https://doi.org/10.1007/ BF03007341

O'Callaghan JF, Mark DM (1984) The extraction of drainage networks from digital elevation data. Comput Vis Graph Image Process 28(3):328-344. https://doi.org/10.1016/S0734-189X(84)80011-0

Ozdemir H, Bird D (2009) Evaluation of morphometric parameters of drainage networks derived from topographic maps and DEM in point floods. Environ Geol 56(7):1405-1415. https://doi. org/10.1007/s00254-008-1235-y

Pandžić K, Trninić D (1992) Principal component analysis of a river basin discharge and precipitation anomaly fields associated with the global circulation. J Hydrol 132(1-4):343-360. https://doi. org/10.1016/0022-1694(92)90185-X
Prasad RK, Mondal NC, Banerjee P, Nandakumar MV, Singh VS (2008) Deciphering potential groundwater zone in hard rock through the application of GIS. Environ Geol 55(3):467-475. https://doi.org/10.1007/s00254-007-0992-3

Puno GR, Puno RCC (2019) Watershed conservation prioritization using geomorphometric and land use-land cover parameters. Glob J Environ Sci Manag 5(3):279-294

Rahaman SA, Ajeez SA, Aruchamy S, Jegankumar R (2015) Prioritization of sub watershed based on morphometric characteristics using fuzzy analytical hierarchy process and geographical information system: a study of Kallar watershed, Tamil Nadu. Aquatic Procedia 4:1322-1330. https://doi.org/10.1016/j.aqpro.2015.02.172

Rai PK, Mishra S, Ahmad A, Mohan K (2014) A GIS-based approach in drainage morphometric analysis of Kanhar river basin, India. Appl Water Sci 7:217-232. https://doi.org/10.1007/s1320 1-014-0238-y

Rai PK, Chaubey PK, Mohan K, Singh P (2017a) Geoinformatics for assessing the inferences of quantitative drainage morphometry of the Narmada Basin in India. Appl Geomat 9(3):1-23. https://doi. org/10.1007/s12518-017-0191-1

Rai PK, Mishra VN, Mohan K (2017b) A study of morphometric evaluation of the Son basin, India using geospatial approach. Remote Sens Appl Soc Environ 7:9-20. https://doi.org/10.1016/j.rsase .2017.05.001

Rai PK, Chandel RS, Mishra VN, Singh P (2018) Hydrological inferences through morphometric analysis of lower Kosi river basin of India for water resource management based on remote sensing data. Appl Water Sci 8:15. https://doi.org/10.1007/s1320 1-018-0660-7

Rai PK, Singh P, Mishra VN, Singh A, Sajan B, Shahi AP (2019) Geospatial approach for quantitative drainage morphometric analysis of Varuna river basin, India. J Landsc Ecol 12(2):1-25. https:// doi.org/10.2478/jlecol-2019-0007

Ratnam KN, Srivastava YK, Rao VV, Amminedu E, Murthy KSR (2005) Check dam positioning by prioritization of micro-watersheds using SYI model and Morphometric analysis-remote sensing and GIS perspective. J Indian Soc Remote Sens 33(1):25-38. https://doi.org/10.1007/BF02989988

Reddy GPO, Maji AK, Gajbhiye KS (2002) GIS for morphometric analysis of drainage basins. GIS lndia 4(11):9-14

Reddy GPO, Maji AK, Gajbhiye KS (2004) Drainage morphometry and its influence on landform characteristics in a basaltic terrain, Central India - a remote sensing and GIS approach. Int J Appl Earth Obs Geoinform 6(1):1-16. https://doi.org/10.1016/j. jag.2004.06.003

Samani N, Gohari-Moghadam M, Safavi AA (2007) A simple neural network model for the determination of aquifer parameters. J Hydrol 340(1-2):1-11. https://doi.org/10.1016/j.jhydr ol.2007.03.017

Schumm SA (1956) Evolution of drainage systems and slopes in badlands at Perth Amboy. New Jersey. Bull Geol Soc Am 67(5):597646. https://doi.org/10.1130/0016-7606(1956)67\%5b597:eodsa s\%5d2.0.co;2

Sethupathi AS, Lakshmi NC, Vasanthamohan V, Mohan SP (2011) Prioritization of mini watersheds based on morphometric analysis using remote sensing and GIS in a drought prone Bargur Mathur sub watersheds, Ponnaiyar River basin, India. Int J Geomat Geosci 2(2):403-414

Sharma A, Singh P, Rai PK (2018) Morphotectonic analysis of Sheer Khadd River basin using geo-spatial tools. Spat Inf Res 26(4):405. https://doi.org/10.1007/s41324-018-0185-z

Singh S, Singh MC (1997) Morphometric analysis of Kanhar river basin. Natl Geogr J India 43(1):31-43

Singh P, Thakur JK, Singh UC (2013) Morphometric analysis of Morar river basin, Madhya Pradesh, India, using remote sensing and GIS techniques. Environ Earth Sci 68:1967-1977 
Singh P, Gupta A, Singh M (2014) Hydrological inferences from watershed analysis for water resource management using remote sensing and GIS techniques. Egypt J Remote Sens Space Sci 17(2):111-121. https://doi.org/10.1016/j.ejrs.2014.09.003

Sreedevi PD, Sreekanth PD, Khan HH, Ahmed S (2013) Drainage morphometry and its influence on hydrology in a semi-arid region: using SRTM data and GIS. Environ Earth Sci 70(2):839-848. https://doi.org/10.1007/s12665-012-2172-3

Strahler AN (1957) Quantitative analysis of watershed geomorphology. Trans Am Geophys Union 38:913-920. https://doi.org/10.1029/ TR038i006p00913

Strahler AN (1964) Quantitative geomorphology of drainage basins and channel network. In: Chow V (ed) Handbook of applied hydrology. McGraw-Hill, New York, pp 439-476

Thomas J, Joseph S, Thrivikramji KP, Abe G, Kannan N (2012) Morphometrical analysis of two tropical mountain river basins of contrasting environmental settings, the southern Western Ghats, India. Environ Earth Sci 66(8):2353-2366. https://doi. org/10.1007/s12665-011-1457-2
Vittala SS, Govindiah S, Gowda HH (2004) Morphometric analysis of sub-watersheds in the pavagada area of Tumkur district, South India, using remote sensing and GIS techniques. J Indian Soc Remote Sens 32(4):351-362. https://doi.org/10.1007/BF03030860

Yadav SK, Singh SK, Gupta M, Srivastava KP (2014) Morphometric analysis of Upper Tons basin from Northern Foreland of Peninsular India using CARTOSAT satellite and GIS. Geocarto Int 29(8):895-914. https://doi.org/10.1080/10106049.2013.868043

Zavoianu I (1985) Morphometry of drainage basins (Developments in Water Science). Elsevier, Amsterdam, ISBN: 0-444-99587-0. https://www.elsevier.com/books/morphometry-of-drainage-basin s/zavoianu/978-0-444-99587-2

Publisher's Note Springer Nature remains neutral with regard to jurisdictional claims in published maps and institutional affiliations. 